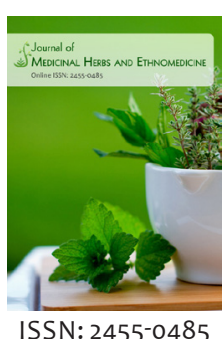

Received: May 11, 2021 Revised: June 24, 2021 Accepted: June 27, 2021 Published: July 06, 2021

*Corresponding Author: Gustavo J. Martínez E-mail: gustmart@yahoo. com

\section{Medicinal plants of ethnopharmacological relevance in Sierra de Ancasti, Catamarca, Argentina}

\author{
Gustavo J. Martínez* \\ IDACOR (Conicet)/Museo de Antropología (Universidad Nacional de Córdoba). Hipólito Yrigoyen 174, Córdoba. \\ República Argentina
}

\begin{abstract}
The aim of this work is to document the knowledge, significance, and uses of medicinal plants in the rural population of Ancasti, Catamarca, Argentina, considered an area of great biodiversity. The community defines itself as criollos-serranos and its subsistence economy is associated with traditional livestock production systems and small-scale agriculture. The techniques used in ethnobiology were adopted as a methodological framework. Informants were selected intentionally based on their expertise or by snowball sampling. The specific information about the topic was gathered by records and documentation of species, open interviews and specific semi-structured surveys, participant observation and records of a rapid rural diagnosis. For quantitative analysis, two indices were applied, including: Relative Importance (RI), and Informant Consensus Factor (ICF). A total of 209 medicinal plant and 5 species of fungi belonging to 70 families were recorded. Asteraceae was dominating with 25 species. Herbs were leading with a $45 \%$ contribution, followed by shrubs. The RI index highlights species like Rosmarinus officinalis, Vachellia caven and Cestrum parqui, also others rarely referred to in previous studies, as in the case of Lithraea molleoides. The medicinal flora in Ancasti, Catamarca is highly diverse and remained scarcely explored so far. Its composition accounts for a set of species and applications that are shared with those of other regions of central and northwestern Argentina, highlighting the presence of intercultural contacts.
\end{abstract}

KEYWORDS: Ancasti, medicinal flora diversity, criollos-serranos

\section{INTRODUCTION}

One of the most remarkable things about ethnobotany is its dedication to the recovery and study of the knowledge that societies, ethnic groups and cultures around the world had and still have, about the properties of plants and their use to satisfy human needs. In this sense, traditional knowledge can offer sustainable alternatives for the future, both in terms of technology and development, as well as a necessary respectful coexistence of social communities with each other and with the environment (Anderson et al., 2011). For all this, we consider important to rescue and revalueate the traditional knowledge of the autochthonous medicinal flora, which is part of the cultural heritage and identity of the peoples. On the other hand, the information provided by this type of studies can be useful and applicable for the conservation of plant genetic resources linked to the subsistence of the inhabitants, in particular for their health, when it refers to medicinal plants.

Traditional medicinal systems are mainly characterisized by the use of plants for treating health problems. Herbal medicine has been an essential part of the health system in many traditional societies. Nearly $80 \%$ of the world population resorts to traditional medicine for treating their diseases, which is mainly based on the use of extracts and active substances from medicinal plants; two-thirds of these plants come from underdeveloped countries (WHO, 1978a,b; Alonso and Desmarchelier, 2005; Barboza et al., 2009). In the declaration of Alma-Ata, WHO insists on the need to reassess the use of plant pharmacopoeia in health care (WHO, 1978b).

Although the bibliography on the use of plants in traditional Argentine medicine is extensive specific studies on medicinal plants in central Argentina are less common, despite having gained increasing interest in recent decades.

This knowledge of the rural inhabitants of central Argentina has been explored from an ethnobotanical and ethnomedical point of view, including for Córdoba: the works by Arias Toledo (2006, 2009), Arias Toledo et al. (2007, 2009, 2010); Trillo et al. (2010) and Menseguez et al. (2007) in the Tulumba department; the work of Goleniowski et al. (2006) for the Comechingones mountain ranges; the research by Martínez (2005, 2007, 2008, 2010) and Martínez and Planchuelo (2003) in the intermountain valleys of Paravachasca and Calamuchita in the south of the

Copyright: (c) The authors. This article is open access and licensed under the terms of the Creative Commons Attribution License (http://creativecommons.org/licenses/by/4.0/) which permits unrestricted, use, distribution and reproduction in any medium, or format for any purpose, even commercially provided the work is properly cited. Attribution - You must give appropriate credit, provide a link to the license, and indicate if changes were made. 
province of Córdoba; the studies by Luján and Martínez (2017) to compare urban and rural populations, and Luján et al. (2017) for the Traslasierra valley, San Javier department. Meanwhile, for the Cuyo region (San Juan province), a series of popular publications arising from collaborative research processes with rural schools is known (Karlin, 2006; Karlin et al., 2005). Additionally, as part of the general floras, contributions are known for the province of Córdoba (Barboza et al., 2006) and the Famatina locality in La Rioja province (Cantero et al., 2015). Nearly to the study area, in the Puna region, Pérez de Nucci (1998) and Palma (1973) described the traditional medicine in the Northwest of Argentina, and Hilgert (2001) characterized domestic medicine in the Yungas ecosystem in Salta province.

With respect the province that concerns us, Catamarca, there is little tradition in ethnobotanical studies. The information comes from folkloric sources such as the well-known glossary by Villafuerte (1961), which includes a list with the names of some plants and their applications.

Given the scarcity of ethnobotanical information in this region and the process of cultural loss and erosion (Martin, 2001), there is an urgent need to document it before it is too late. Therefore, the aim of this work is to document the knowledge, significance, and uses of medicinal plants in the rural population of Ancasti, Catamarca, Argentina.

\section{MATERIAL AND METHODS}

\section{Study Area and Population}

Located east of the province of Catamarca, the Ancasti mountain range (Figure 1) is over 1,200 meters of altitude and is considered an area of great biodiversity where the following ecoregions converge: Yungas (Selva de Transición, Selva Montana) [Yungas]; Monte de Sierras y Bolsones [Argentine Northwest Monte]; and Chaco Seco (Chaco Semiárido y Serrano) [Dry Chaco] (Maldonado, 2011; Morláns, 1995; Palmeri et al., 2008). Regarding the vegetal structure, the area is characterized by combining tree elements typical of the Chaco Semiárido, such as Celtis spp., Geoffroea decorticans (Gillies ex Hook. and Arn) Burkart., Jodina rhombifolia (Hook. and Arn.) Reissek and Schinopsis lorentzii (Griseb.) with elements typical of Chaco Serrano, such as Parapiptadenia excelsa (Griseb.) Burkart, Prosopis nigra (Griseb.) Hieron, and Zanthoxylum coco Gillies ex Hook. f. and Arn., as well as species more related with Selva de Transición, such as Anadenanthera colubrina (Vell.) Brenan, Erythroxylum argentinum O.E. Schulz and Xylosma pubescens Griseb.

According to the latest national census, the department of Ancasti is made up of a population of 2,917 inhabitants, distributed in 786 households (INDEC, 2010). The department is divided into 10 districts, where populations with little demographic concentration are settled, the only municipality being Villa de Ancasti (305 inhabitants). The rest of the population is scattered in hamlets and places that make up the typical rural appearance of the area (Jiménez-Escobar, 2019).
The community defines itself as criollos-serranos and its subsistence economy is associated with traditional livestock production systems (cattle, goats, and sheep) and small-scale agriculture, mainly maiz (corn) (Zea mays L.) and zapallo (squash) (Cucurbita maxima Duch.). Currently, a recent migration of small Catamarca producers to urban centers is observed due, among other reasons, to changes in land use (Jiménez Escobar and Martínez, 2019).

In relation to its health system, the province of Catamarca is divided into 12 programmatic areas; each of them has an Area Chief and a Healthcare Director in charge. The Ancasti Department belongs to Programmatic Area No. 7, a territorial space which includes the Municipalities of Ancasti, Icaño and part of La Paz; where the centrality in administration, management and coordination of the area, is in the Icaño District Hospital.

The health system in Ancasti is made up of a District Hospital, a Sectional Hospital and Peripheral Health Posts located in towns with a concentrated and dispersed population. Ancasti Hospital is the only health facility with permanent medical care. Currently $82.84 \%$ of the population of Ancasti is covered by PHC; this implies that $82.84 \%$ formally have a health agent in charge, working at collecting health information and executing PHC actions required by the central administration (weight and height control, vaccinations, identification of pregnant women, etc.) (Ochoa and Fernández, 2014).

\section{Ethnobotanical Trips and Surveys}

As methodological framework, techniques commonly used in ethnobiology were used (Albuquerque et al., 2010; Anderson et al., 2011; Martin, 2001). Prior to the interviews with the residents, the research project and its objectives were reported both to the municipal representatives and the State Office for Environment and Development in the province. Likewise, this was reported to the members of the community and, individually, to each household, in which a verbal consent was requested in accordance with the Code of Ethics of the International Society of Ethnobiology (2006). Informants were selected intentionally based on their expertise, snowball sampling, or inhabitants' interest in taking part in the project.

The specific information about the topic was gathered at different stages of the research process, namely:

a) Records and documentation of species, vernacular names and uses in general, within the framework of ethnobotanical walks with qualified informants.

b) Open interviews and specific semi-structured surveys on traditional medicine with local actors: ethnobotanical survey guidelines were followed for Gran Chaco (Arenas 1995), which helped obtain information about the traditional diagnostic and healing practices, with a focus on traditional medicinal plant uses.

c) Participant observation.

d) Records of a rapid rural diagnosis (Rifkin 2007) in local health centers by consulting professionals from the regional hospital and dispensaries. 


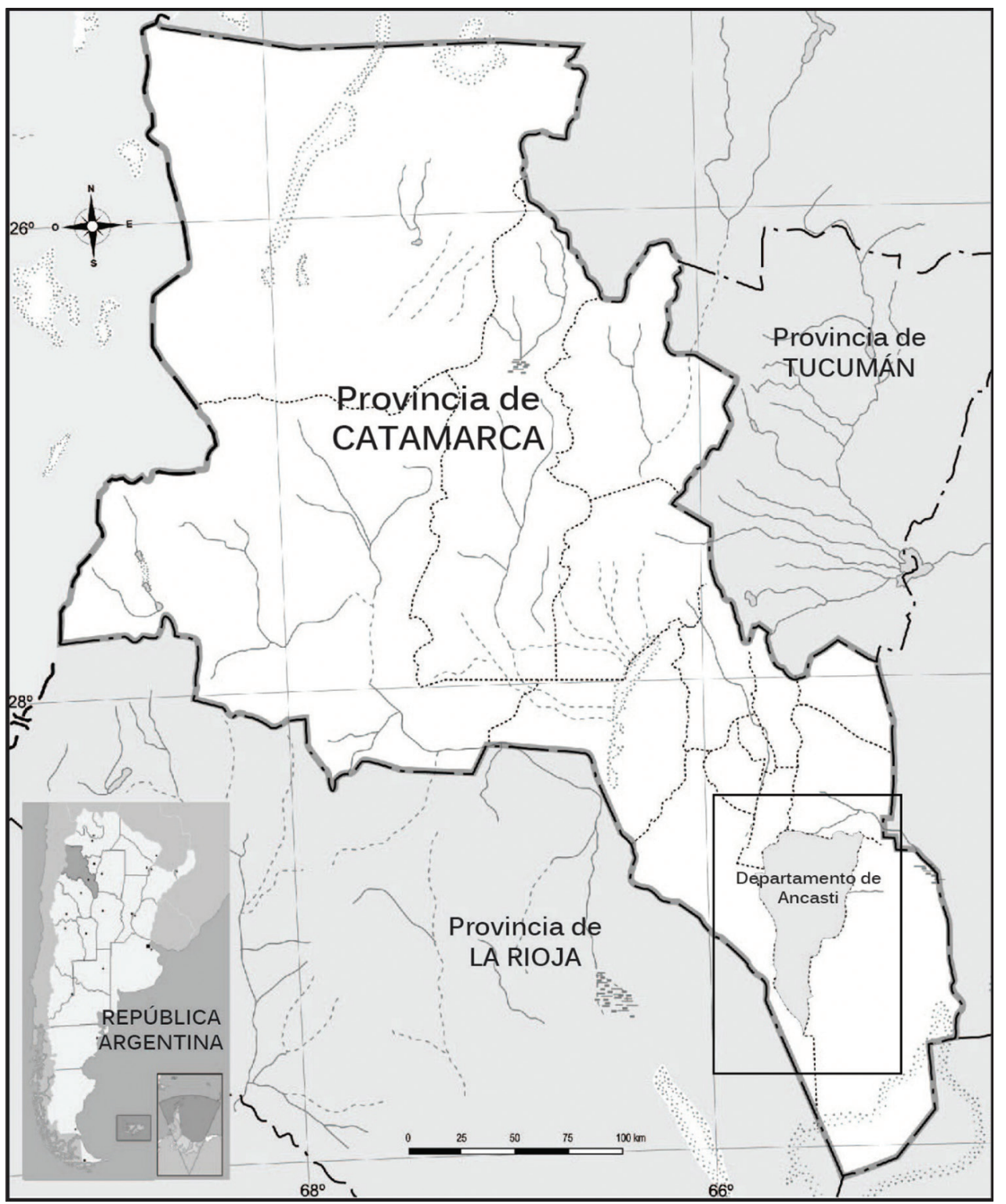

Figure 1: Location of the study area, Ancasti department, Catamarca province, Argentina.

The interview material was registered in digital recordings and in field notebooks. The plants were collected mainly in a reproductive state for later identification. The collection was processed according to established standards (Alexiades, 1996). The specimens were determined by the author and, subsequently, deposited in the Herbarium of the Botanical Museum (CORD), of the Multidisciplinary Institute of Plant Biology (IMBIV), National University of Córdoba, Argentina under the numbering series GJ. Martínez (GJM) and ND. Jiménez-Escobar (NDJE). The list of species follows the taxonomic proposal and nomenclature established in the Catalogue of Vascular Plants of the southern cone (Zuloaga et al., 2008).

\section{DataAnalysis}

The ethnobotanical information was systematized in an Excel database through the dynamic tables function for its analysis.
The following indices were applied:

a) Relative Importance

Relative Importance (RI) for each medicinal species was calculated following Bennet and Prance (2000) based on the normalized number of pharmacological properties attributed to it and the normalized number of body systems (BS) it affects, using the given formula:

$$
\mathrm{RI}=(\text { Rel PH }+ \text { Rel BS }) \times 100 / 2
$$

Rel PH $=$ PH for a given plant/Maximum PH of all reported plant species

Where: PH is the pharmacological attribute of the selected plants (according to an etic perspective), and Rel PH, the 
relative number of pharmacological properties attributed to individual plant species.

Rel $\mathrm{BS}=\mathrm{BS}$ of a given plant/Maximum BS of all reported plant species

BS is the number of body systems healed up by using single species, and Rel BS, the relative number of body systems healed up by using a single species.

\section{b) Informant Consensus Factor}

The Informant Consensus Factor (ICF) was used to see if there was agreement in the use of plants in the ailment categories between the plant users in the study area. The ICF was calculated using the following formula (Trotter and Logan, 1986; Heinrich et al., 1998):

$$
\mathrm{ICF}=(\mathrm{Nur}-\mathrm{Nt}) /(\mathrm{Nur}-1)
$$

Where: Nur refers to the number of use-reports for a particular ailment category, and $\mathrm{Nt}$, to the number of taxa used for a particular ailment category by all informants. The product of this factor ranges from 0 to 1 . A high value (close to 1.0) indicates high consensus among informants, since relatively few taxa are used similarly by a large proportion of the informants. A low value indicates that the informants disagree on the taxa to be used in the treatment within a category of illness.

\section{RESULTS AND DISCUSSION}

\section{Local Health Care System and Epidemiology}

According to the rapid rural diagnosis conducted, among the most common childhood diseases we find the flu, gastric and liver diseases, diarrhea, fevers, sore throats, neurological seizures. The most common ailments in adults are heart disease, blood pressure, hypercholesterolemia, osteoarthritis (due to the intensity of field work). The district hospital of Ancasti is a place for the control of the vaccination card up to 16 years of age, control of healthy children, head circumference, weight and height and where people stock up on milk. The analyzes, x-rays, ultrasounds are derived to Icaño, a town belonging to the La Paz Department. With regard to maternal and child health, pregnancy control is carried out during the first month and there is no delivery care, except for emergencies, generally deriving to maternity in the capital of Catamarca. An obstacle in the care of maternal and child health is the delay in the control of pregnancy, since younger women often do not know the dates of their last menstruations or the time of pregnancy, postponing much the controls, which sometimes are when contractions and labor are imminent. The prescription of plants among those who are cared for in the hospital, according to the opinion of biomedicals, is not common, although sometimes they buy preparations in herbal stores to treat osteoarthritis and diabetes, ensuring that there were improvements in the patient. Likewise, some health agents remember popular recipes with which patients have used to treat their ailments.

Health agents also noted that the influence of home or domestic medicine and traditional medicine practices which contribute to the primary health care system are especially relevant among the most marginalized population. They hold important knowledge about plant, animal and medicinal mineral species, although this knowledge is also similarly distributed in the general population of the study area. Conversely, the figure of the healer or traditional practitioner is not central to the treatment and management of specialized diseases and ailments with medicinal plants.

A part of the population is treated collaterally to the official health system, and they are generally the group of artisans who seek respected childbirth, are opposed to vaccines, and make their own medicinal preparations with local products. The midwives, for their part, are not frequently found in the area, since gyneco-obstetric care is conducted in the municipal hospitals of the region.

One of the most documented aspects among non-indigenous populations throughout the Americas and which manifests itself in the context of these practices is the validity of reformulated principles of humoral medicine and the notions of "warm" and "cold" in the classification of diseases, food, therapies and even among plants (Foster 1994; Idoyaga Molina 2000). On the basis of these theories, it is understood that an imbalance caused by excess heat or cold impacts on the etiology of various diseases, which is why, in the therapeutic field, attempts are made to restore the lost balance through the use of "cold" and "hot" plants for some cases. However, these aspects appeared only seldom among the criteria for selecting medicinal species for a given ailment or recipe. One of the few and most illustrative examples is the use of the leaves of hediondilla (Cestrum parqui LHér.) which are applied in poultices on the temples to relief headaches, and with cold water in sitz baths to treat stomach ache caused by heats; it is also used as a venous antiinflammatory to relieve leg pain. Besides, clothes are washed with a soap made with hediondilla to treat hemorrhoids and as a skin healer. The leaf of this plant is also applied between underwear and the anus, and are placed under the hat or on the neck to provide protect against sun poisoning. Since it is fresh, "four leaves are put between the underwear and the buttocks to avoid the heat of the saddle and steam"; with iguana fat, it "sucks the dirt" from pimples and boils. Finally, it relieves itching caused by the sun heat.

\section{1) Diversity and composition of ethnomedical flora}

A total of 702 uses corresponding to 209 medicinal plant and 5 fungi species belonging to 70 families, which were used by local communities to treat 12 disease categories, were recorded (Table 1).

\section{a) Most relevant Families}

As shown in Figure 2, Asteraceae was dominating with 25 species and 78 uses, followed by the Fabaceae (15 spp./42 uses), 
Table 1: List of medicinal species and uses with their recipes in Sierra de Ancasti, Catamarca, Argentina

\begin{tabular}{lll}
\hline Family & Vernacular name & Recipes \\
Species (Voucher) & \\
\hline
\end{tabular}

FUNGI

AGARICACEAE

Mycenastrum corium (Guers.) polvo del zorro, hongo de Spores used topically to treat "soft foot corns" or athlete's foot injuries.

Desv. (GJM 1318) / Lanopila la tierra, flor de la tierra Spores used topically to treat burns and scalds that occur when children urinate.

bicolor (Lév.) Pat.

(GJM 1037)

Whipped egg applied with the spores to treat burns. Spores applied to heal wounds, injuries, pimples and infections.

LYCOPERDACEAE

Spores used to heal the umbilical cord.

Calvatia fragilis (GJM 1255, polvo del zorro, polvillo del Spores are used topically to treat burns; also, to treat scalds that occur when children

GJM 1296)

zorro, hongo de la tierra urinate.

PARMELIACEAE

Its spores are applied to heal wounds, injuries, pimples and infections.

Usnea aff. barbata (L.) Weber barba de la peña, barba de It is placed in footwear to prevent perspiration of the feet.

ex F.H. Wigg. (GJM 1370) monte As an infusion or in mate, it is drunk for high blood pressure.

Usnea amblyoclada (Müll. barba de piedra

It is prepared in decoction to treat kidney conditions and stones.

Arg.) Zahlbr. (GJM 1170)

Frictions of its infusion are drunk or applied for joint pains, fractures, sprains and leg pains. It is used in decoction to treat foot pain due to its iodine content. With rompepiedras and cola de caballo, an infusion is prepared to relieve kidney discomfort or waist pain.

In decoction, to treat kidney conditions and stones.

To treat tonsillitis and throat conditions, gargles with its decoction and salt are made. An infusion in hot water on an empty stomach dissolves gallbladder stones.

The infusion is applied to rinse the mouth out for relieving toothaches.

The infusion is drunk for liver and digestive conditions.

PLANTAE

ADOXACEAE

Sambucus sp.

saúco

Infusion with leaves drunk as a fresh beverage to help measles ooze.

AMARANTHACEAE

yerba del pollo

GJM 1291)

Decoction of the root with malva and menta leaves prepared for constipation. It is also prepared as an infusion with burnt sugar.

Tea prepared and taken for an upset stomach or as digestive conditions and diarrhea. For upset stomach, an informant proposes the following recipe: Some maíz, rice, noodles, and bread are burned, and a tea is prepared boiling all these with three yerba de pollo roots, which works as a purgative.

Amaranthus sp. yerba meona (GJM 1434)

AMARYLLIDACEAE

Allium cepa L.

cebolla

The decoction of its aerial part is used for liver conditions and to relieve an upset stomach. It may be combined with menta.

In cases of nosebleeds, the cebolla smell is provided for aspiration, or the sign of the cross is made with it on the head.

The infusion of its cataphylls is applied as a pain reliever for sore throats.

A jug of water is prepared with cebolla peels and 2 tablespoons of honey and is then provided as a drink for colds, sore throats and cough. For the same purpose, it is combined with toasted naranja peel and quimpe. It is also prepared with Coca-Cola. With salvia blanca and limón as an infusion. It is also ingested raw.

Allium sativum $\mathrm{L}$.

The intake of its bulb is prescribed to lower cholesterol and treat "thick blood."

Half a warm bulb is applied with cotton to relieve ear ache.

A piece of bulb is applied locally to treat oral conditions.

Ajo intake is purifying and boosts blood circulation.

Ajo intake prevents strokes, as it lowers blood pressure and "relieves" the blood. It is usually left in a glass of water for a day and is drunk on an empty stomach.

Raw ajo is consumed to relieve asthma and lung conditions.

A symbolic action is applied, which includes thrusting into an ajo and removing the cloves, which are then threaded while perforating the warts. After that, 3 Our Father prayers are to be said, and where the cloves are left should be unknown. In other cases, the ajo clove is rubbed in the "soft foot corn" or wart nucleus.

In case of bites by poisonous animals (vipers or insects,) a clove of ajo is ingested. Ajo or ajo milk is ingested on an empty stomach for intestinal parasites; prior to this, a tablespoon of sugar or honey is given to attract them; they are also cured with words. Ajo with tomato is also ingested for parasites. 
Table 1: (Continued)

Family Vernacular name Recipes

\section{Species (Voucher)}

ANACARDIACEAE

Lithraea molleoides (Vell.) molle, molle Córdoba, molle cordobés, molle de beber

Schinopsis lorentzii (Griseb.) quebracho colorado Engl. (GJM 950)

Schinus areira L. (NDJE 2342)terebinto, aguaribay

Schinus fasciculatus (Griseb.) molle tonto, molle tonto, I.M. Johnst. var. fasciculatus molle sonso, molle (GJM 1263) incienso, molle pispo
As a fresh beverage, infusion or in mate, it relieves bone pain.

The decoction of its leaves with honey is consumed as flu medicine and for colds. It is also combined with salvia blanca leaves and naranja peels with toasted sugar as a homemade remedy.

The infusion of its leaves is recommended as a cough suppressant.

The fruit is consumed by adding it to mate.

For headaches from the sun or heat, a head wash is used; it can be combined with sauce and tusca.

As an infusion (or a fresh infusion), it is drunk for blood conditions such as cholesterol, causing it to "relieve." It is also applied with sombra de toro and/or poleo. It is pointed out, however, that it is "makes you angry," that is to say, it causes stinging, that is why it is barely used with frequency.

The infusion of its leaves is drunk to lower cholesterol and treat "thick blood."

It is used alone in aguapasto to treat uric acid, or combined with infusion of sombra de toro leaves. It helps the blood "slim" along with the sombra de toro leaves.

The "acid" or caustic liquid that comes out when cutting the fruit is applied for 2 or 3 days on warts until they are burned.

A terebinto decoction is prepared with granada husk and toasted sugar on a hot coal for diarrhea cases.

The bitter infusion of the leaves is drunk for liver conditions.

Hot fomentations are prepared with jarilla to treat strains and sprains; it is anti-

inflammatory and relieves pain.

Molle sonso incense is perfumed with chicken fat to relieve respiratory problems caused by the "air."

The boiled leaves are used with salt to rinse the mouth out and relieve canker sores and mouth sores.

As a tea, it acts as an oxytocic which helps release the retained placenta; for the same purpose, the handles of a pair of scissors is placed in the mouth so that the woman retches. A wash with the leaves is used to treat pain in the feet and deflate them.

It is used to treat and fix fractures, with sugar, yerba and molle tonto resin, since it takes out the "air."

It is used to treat the fall of the paletilla shoulder-blade, which causes vomiting and diarrhea. It is applied as "patches" with sugar, yerba and the molle tonto resin.

It is prescribed as an infusion for liver pains when overdrinking.

A molle sonso, manzanilla and salvia lora tea is prescribed in case of vomiting as an antiemetic.

Alone or a mixture of 3 herbs is prepared: membrillo, piscoyuyo, and molle pispo. It is drunk as a tea to treat diarrhea. A boiled molle tonto water is also prepared and a fairly "chullito" starch is dissolved, that is light liquid, not thick.

There are two: guiador and redondito, whose smell is bad and strong. The infusion of the leaf is used for stomach aches, but it is strong.

\section{APIACEAE}

Ammi visnaga (L.) Lam. (GJM cilantro de zorro 1485)

Apium graveolens L. (GJM apio

1497)

The infusion of the aerial part is drunk as an antihemorrhagic agent

The leaves are prepared as an infusion with romero and paico and taken as a blood purifier. The infusion is used for high blood pressure.

Apio as a fresh beverage or in mate relieves urinary infections and is drunk as an antinephritic remedy.

A tea with orégano, apio, té de burro and poleo is prepared to "correct" the stomach. It is also combined with apio, orégano and hinojo for infections or the heat that affects the intestines when a meal makes you sick and causes stomach heaviness. This corrects pain and swelling of the abdomen.

An infusion with aguardiante liquor is prescribed for fertilizing purposes.

An apio tea with aguardiente liquor is given to relieve postpartum pain and promote the recovery of the woman's body; chicken soup is also provided.

Coriandrum sativum L. cilantro

For cases of confinement (the placenta is not eliminated,) a homemade remedy with poleo, paico, romero and toasted cilantro seeds is prescribed, since they work as oxytocics.

An infusion with anis is prescribed to boost breast milk production.

In decoction with hinojo, it is drunk to relieve menstrual cramps and release retained placenta.

The aerial part as an infusion to relieve flatulence.

In mystery: chamico, hinojo and malva are boiled, and twigs are added for a sitz bath when a child's body temperature rises (after he/she has sat on very hot ground.)

Hinojo tea for infections, or "belly twitch," with orégano and apio. 
Table 1: (Continued)

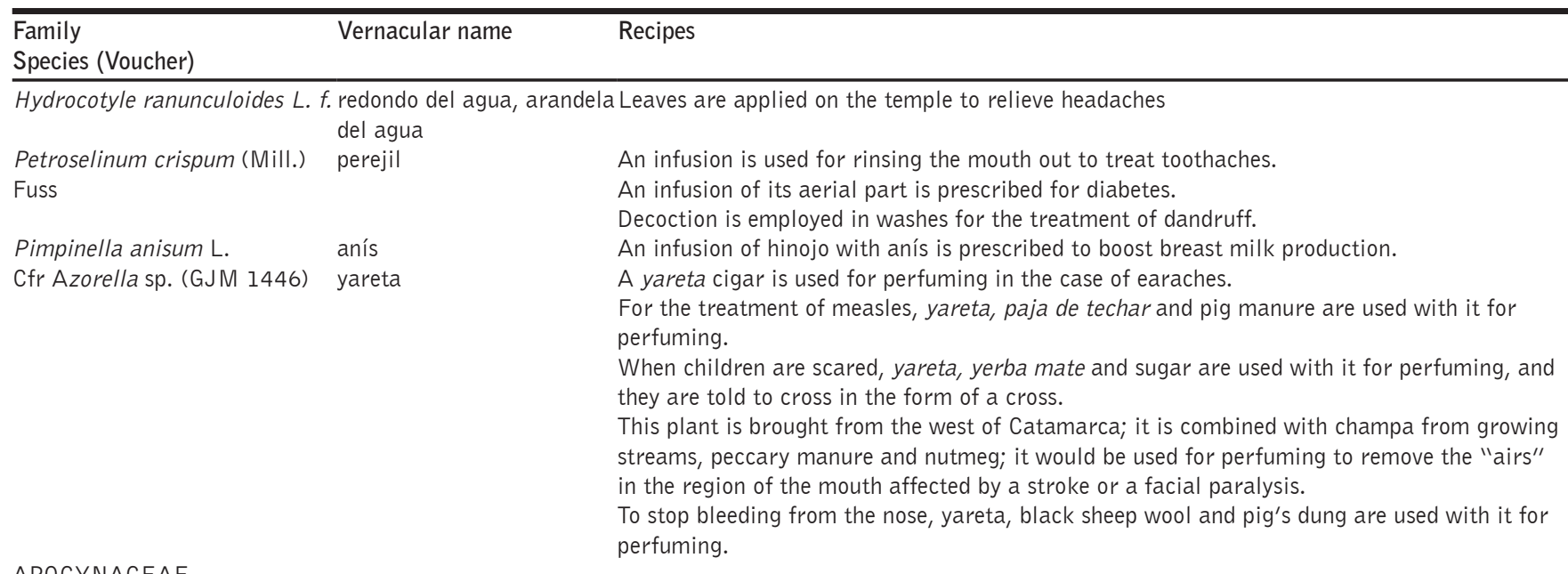

APOCYNACEAE

Araujia brachystephana

(Griseb.) Fontella \& Goyder

(GJM 1299)

Aspidosperma quebracho-

blanco Schltdl. (GJM 1239)

Vallesia glabra (Cav.) Link ancoche

(GJM 932)

AQUIFOLIACEAE

Ilex paraguariensis A.St.-Hil. yerba, yerba mate

doca

quebracho blanco
ARISTOLOCHIACEAE

Aristolochia argentina Griseb. charrua

(GJM 1190)

Prosopanche americana (R.Br.) guaycurú, costilla de la

Baill. (GJM 1358) tierra

\section{ASPARAGACEAE}

Agave americana L. (NDJE pita

2340)

ASTERACEAE

Achyrocline satureioides

(Lam.) DC. (GJM 1284)

Artemisia douglasiana Besser buscapina, pata de rana, (GJM 1363)
The decoction of its root boosts breast milk production.

To treat pimples and heal thorn wounds, a piece of paper with doca latex is placed.

The infusion of its fruits is applied in washes as a pediculicide.

Leaf decoction is used to treat fleas.

The decoction of its leaves is used in washes to treat pediculosis.

The perfume of yerba and sugar relieves ear conditions.

To wean, the nipple was moisturized with yerba mate.

Yerba mate tea bags with milk are drunk to boost breast milk production.

Yerba, sugar and pig manure are used with it for perfuming in cases of molle and quebracho

"stings" or bee stings.

Yerba, sugar, romero and beeswax (Plebeia molesta) are used for perfuming.

The sign of the cross is made with a burned stick of yerba mate to treat warts.

It is drunk in mate without sugar for diabetes cases.

To treat enuresis or fecal incontinence due to "colds" in the bladder or intestine, yareta, black sheep wool and yerba mate are used with it for perfuming.

An infusion of "yerba mate water" is inhaled to relieve colds.

Yerba and sugar are used with it for perfuming and as an antieruptive (measles and chicken pox); wind exposure is to be avoided for three days to prevent measles from going "inside." Yerba, sugar and pig manure are used with it for perfuming those children who suffer from the "air" and turn their eyes back due to drafts and strong winds, which make them cry and feel discomfort.

It is used to treat the fall of the paletilla shoulder-blade, which causes vomiting and diarrhea. It is applied as "patches" with sugar, yerba and molle tonto resin. When a child's the paletilla shoulder-blade falls due to a fright, he/she is perfumed with it, and also with yerba and sugar.

A folded leaf is placed inside the ear canal for 1 or 2 days until it dries, and the heat that causes the air buzzing comes out.

A fresh beverage (in a fresh decoction) is made with its root to purify the blood.

A fresh beverage (in a fresh decoction) is made with its root for the kidneys.

The infusion of its root is used to treat asthma. "Before you would take a piece of the root and put it up your..., people would be in good health for a long time! "

The maceration in alcohol of pita leaves and romero is applied to relieve rheumatism.

The infusion of its leaves is prescribed for respiratory conditions.

The Buscapina infusion is used to treat vomiting and a hepatic agent. The infusion is diuretic. 
Table 1: (Continued)

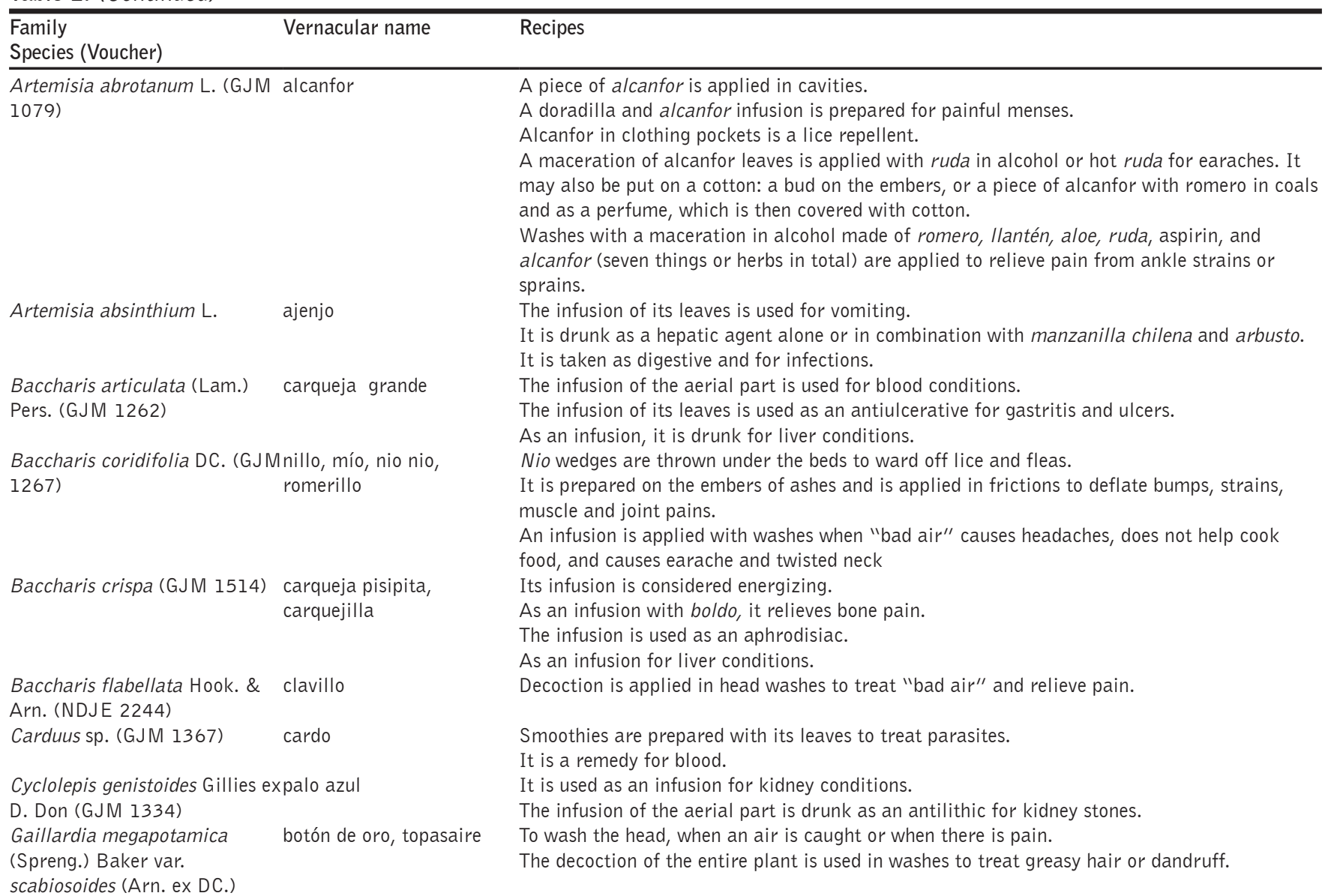

Baker (GJM 1149)

Lactuca sativa L. lechuga

The higuera and lechuga leaves are drunk as a fresh beverage to regulate blood pressure.

It is prescribed as an infusion for nervousness. It can also be combined with mandarina and/ or tilo water.

Matricaria chamomilla L. manzanilla, manzanilla An infusion of manzanilla flowers is applied in a bag of boiled water to relieve eye pain. dulce

For toothaches, a manzanilla dulce flower cigarette is applied.

The infusion of their inflorescences is used to relieve vomiting.

Decoction of the inflorescences is drunk for menstrual cramps.

A decoction is prescribed to relieve gas.

An infusion of manzanilla and paico is used to treat constipation.

An infusion of manzanilla and tilo is used to lose weight and remove adiposities.

Frictions of chicken fat, manzanilla, and a hot cloth are applied; also with thick altea ointment.

Parthenium hysterophorus L. altamisa

(GJM 1199)

Baths are prescribed with a decoction of the plant to treat pruritus.

It is used to wean children, given its bitter taste.

The infusion of its leaves is used as an antidiabetic.

The infusion is used for liver conditions.

Pectis odorata Griseb. (NDJE manzanilla del campo, 2320)

manzanilla dulce

Pluchea sagittalis (Lam.)

The infusion of its aerial part is drunk as a digestive with mate.

Cabrera (GJM 1244)

Schkuhria pinnata (Lam.)

cuatro cantos, tres cantos The infusion of its leaves is prescribed for liver conditions.

Kuntze ex Thell. (GJM 1280)

matapulgas, canchalagua The maceration of its infused air part is drunk to lower fevers.

For pediculosis, the head is washed with a maceration of canchalagua with soap.

A broom is created with it to sweep fleas, or maceration of water is used for watering.

The flea killer decoction is applied to treat dandruff.

It is a very good herb to wash feet and relieve limb pain.

It is drunk as an infusion for liver conditions. It is recommended for drinkers.

The decoction of its aerial part in water is applied in washes for dandruff (the eyes are to be tightly closed because it is bitter.)

Senecio deferens Griseb. cuatro cantos It is drunk in infusion as a hepatic agent. 
Table 1: (Continued)

\begin{tabular}{|c|c|c|}
\hline $\begin{array}{l}\text { Family } \\
\text { Species (Voucher) }\end{array}$ & Vernacular name & Recipes \\
\hline Tagetes filifolia Lag. & anisillo, suiquillo & $\begin{array}{l}\text { Its infusion is antiemetic. } \\
\text { Its infusion is digestive. } \\
\text { As an infusion, it is a carminative. }\end{array}$ \\
\hline Tanacetum parthenium (L.) & manzanilla amarga, & The infusion is drunk as an appetizer to whet the appetite. \\
\hline Sch. Bip. (GJM 910) & $\begin{array}{l}\text { manzanilla boliviana, } \\
\text { manzanilla chilena }\end{array}$ & $\begin{array}{l}\text { The decoction of this bitter herb is applied in washes to facilitate weaning. } \\
\text { A decoction is employed in washes for eye conditions. } \\
\text { An infusion is prepared with } 2 \text { or } 3 \text { peach leaves for flatulence. } \\
\text { As an infusion, it is used for cases of constipation. } \\
\text { It is drunk as an infusion alone for liver conditions or in combination with arbusto and } \\
\text { ajenjo. A poultice of its inflorescences with chicken or iguana fat is also applied. }\end{array}$ \\
\hline Tanacetum vulgare L. (GJM & arbusto & It is drunk as an infusion for headaches. \\
\hline 911) & & $\begin{array}{l}\text { It is drunk as an infusion alone for digestive and hepatic conditions or in combination with } \\
\text { manzanilla chilena and ajenjo. }\end{array}$ \\
\hline Taraxacum officinale (L.) & diente de león & It is drunk as an infusion to treat liver conditions. \\
\hline Weber ex F.H.Wigg., & & $\begin{array}{l}\text { Its decoction or salad is consumed to stop blood pressure problems. This recipe was learned } \\
\text { from a Peruvian physician who worked in Ancasti. } \\
\text { The leaves are blood purifying. } \\
\text { Its leaves are used to treat kidney conditions. }\end{array}$ \\
\hline $\begin{array}{l}\text { Xanthium spinosum L. var. } \\
\text { spinosum (GJM 904) }\end{array}$ & cepacaballo & $\begin{array}{l}\text { The decoction of its leaves is applied as a healer for wounds. } \\
\text { The sign of the cross is made with its thorns on warts. } \\
\text { An infusion of its leaves is drunk to improve circulation and purify the blood. } \\
\text { The infusion of its leaves dissolves kidney stones. } \\
\text { The infusion of its roots is used for kidney conditions. } \\
\text { The root is considered purifying. } \\
\text { Washes are applied to treat vaginal discharge. } \\
\text { The infusion of its root is drunk after labor. } \\
\text { The infusion of the root is drunk or used in washes for belly infection. }\end{array}$ \\
\hline
\end{tabular}

Borago officinalis L. borraja

BRASSICACEAE

Lepidium didymum L. (GJM quimpe, quimpi

1310)

Nasturtium officinale W.T. berro

Aiton

(GJM 1461)

BROMELIACEAE

Tillandsia sp. (GJM 1528) azahar de chañar

CACTACEAE

Opuntia ficus-indica (L.) Mill. tuna blanca (GJM 1426)

Opuntia quimilo K.Shum

Pfeiffera ianthothele (Monv.)

F.A.C. Weber (GJM 1319)

Rhipsalis aculeata F.A.C.

Weber (GJM 1318) quimile, quimilo

ulvilla

suelda, sueldilla, suelda consuelda
The infusion of its leaves makes the measles "appear outside." The air should not touch it so that the disease does not "get inside."

It is boiled in water to relieve fever; it is especially used in fevers due to eruptive diseases.

It is drunk as an infusion for colds.

For cases of allergy in the eyes, it is scrubbed as a muzzle around the face.

As an infusion with naranja peels, it is applied to make gargles for sore throats.

An infusion is prepared with naranja or limón peel and toasted sugar for coughs; cebolla peel may also be added. An informant prepares an expectorant syrup with quimpe, chañar bark, honey and níspero leaf, as a homemade remedy, and limoan.

As an infusion, it is used for kidney conditions.

The infusion of its root is drunk for hypertension.

As an infusion, it is used for heart conditions.

To cure umbilical hernias, it is applied as a ritual by marking the sole of the foot in the cladode, which is then hung from a thread until it dries.

For gallbladder conditions, a tea is prepared with the tuna criolla blanca flower and it is drunk as a fresh beverage on an empty stomach. It is also left aside and eaten for 15 days. The perfume with the wheat husk (bran) makes eructation appear.

The infusion of its dried flowers (tepals) is drunk for prostate conditions.

The infusion of its dried flowers (tepals) is drunk for kidney conditions.

An infusion is prepared with the dry flower tepals to treat kidney calculus, stones, and conditions. It is a diuretic.

The recently-formed green fruit is cut from the flower of the rib and is drunk as a fresh beverage for the liver.

The ribs are used for symbolic word cures of intestinal parasites.

The cladode is broken, the sign of cross is made and cumin is put; then it is applied in the viper bite as an antivenom.

The ulvilla mucilage is used as a healer.

It is applied in washes for hair treatment and care (anti-seborrheic and anti-dandruff.)

It is ground and used in poultices for snake bites.

The poultices are applied in fractures, strains and sprains. 
Table 1: (Continued)

\begin{tabular}{|c|c|}
\hline $\begin{array}{l}\text { Family } \\
\text { Species (Voucher) }\end{array}$ & Recipes \\
\hline $\begin{array}{l}\text { Trichocereus terscheckii (Parm. cardón } \\
\text { ex Pfeiff.) Britton \& Rose } \\
\text { (GJM 1102) } \\
\text { CAPPARACEAE }\end{array}$ & $\begin{array}{l}\text { For sinusitis, cardón is cut before dawn, the thorns and cover are removed, and with the } \\
\text { "meat," the sign of the cross is made to cut it, and it is then placed on the forehead as a } \\
\text { cataplasm until it dries. }\end{array}$ \\
\hline
\end{tabular}

CAPPARACEAE

Capparis atamisquea Kuntze atamisqu

(GJM 1214)

CAPRIFOLIACEAE

Lonicera japonica Thunb. madreselva

(GJM 1473)

CARYOPHYLLACEAE

Dianthus caryophyllus L. clavel blanco

CELTIDACEAE

Celtis ehrenbergiana (Klotzsch) tala

Liebm. (GJM 905)

Celtis sp.

tala pispo

CERVANTESIACEAE

Jodina rhombifolia (Hook. \& sombra de toro

Arn.) Reissek (GJM 914)

\section{CHENOPODIACEAE}

Dysphania ambrosioides (L.) paico

Mosyakin \& Clemants (GJM

947)

\section{COMMELINACEAE}

Commelina erecta L. (GJM Santa Lucía

879)

CUCURBITACEAE

Citrullus lanatus (Thunb.)

Matsum. \& Nakai

Cucumis sativus L.

Cucurbita maxima Duch.

\section{EPHEDRACEAE}

Ephedra tweediana Fisch. \& tramontana

C.A. Mey. emend. J.H. Hunz.

(GJM 1170)
The decoction of these leaves is used as a digestive.

A tea is prepared for roughness in the throat. Three or four leaves in half a cup of water are recommended.

The flower infusion has tonic properties; thus, it is applied for heart conditions.

A decoction of 3 malva buds, 3 tala shoots, and 3 vid tendrils is prepared to treat diarrhea. It is drunk as an infusion or with milk to avoid constipations and an upset stomach. A midwife from Santa Gertrudis, would prescribe neonates tala and malva water with honeycomb or queyita to get rid of the phlegm that could have been accumulated in the airways. Cow or goat milk with tala leaves is drunk to boost breast milk production.

The decoction of its leaves is applied in washes for eye conditions.

The decoction of its leaves in milk is a carminative.

The tala pispo leaves are boiled with mate tea bags and drunk to boost milk production.

The infusion of its leaves is drunk for kidney conditions.

The decoction of its leaves is drunk as a diuretic.

In a fresh decoction with zarzaparrilla and cola de caballo is drunk to improve blood circulation. A decoction is used for the blood to "slim" and be purified; it is prescribed alone or in combination with molle de beber, with cola de caballo and/or with zarzaparrilla. It is warned that blood pressure may rise.

The infusion of its leaves in tea or mate is used to lower cholesterol or treat "thick blood." It can be combined with molle de beber.

Warts are pierced with the thorny tips of the leaves.

The infusion of its leaves is used to treat uric acid; it can be combined with molle de beber.

Some say it should be drunk for up to 15 days and then suspended.

The infusion of its leaves is drunk with those of romero and apio as a blood purifier.

Paico branches are applied in places where there are fleas.

In decoction or infusion, it is used to treat intestinal worms.

It is consumed as an infusion to whet the appetite.

For cases of confinement (the placenta is not eliminated,) a homemade remedy with poleo, paico, romero and toasted cilantro seeds is prescribed.

To relieve infections in the belly, it is consumed as an infusion with orégano.

The infusion is drunk to stop vomiting.

Contrary to what is believed, some consider that the paico infusion is an antidiarrheal.

As an infusion with burnt sugar, it relieves an upset stomach and infections with laxative

effects. It can be combined with tea and ruda. An informant combines paico with salvia de la

Puna (brought from the Ambato Department) for constipation. With manzanilla, an infusion

is prepared to relieve constipation in children.

A droplet of the beverage or mucilage of the flower bracts is applied to the eye, which relieves any bumps or conjunctivitis in the eyes.

Sandía Consuming its fruit is considered an aphrodisiac.

The white pulp and the peel are thrown under the bed to fight against fleas and lice.

Pepino The slices of this fruit are applied to skin that is burned.

zapallo de Angola, Angola Three peeled of its seeds are consumed on an empty stomach as a vermifuge. Before eating, consume a tablespoon of sugar and a drink aguardiente liquor for three days.

Its infusion is used in washes for the hair treatment.

A decoction is applied in washes to treat varicose veins and leg pain.

A tramontana infusion is drunk for cases of hypertension.

It has blood purifying effects.

The infusion of your aerial part is drunk for diabetes.

The infusion of its aerial part is drunk for cases of high cholesterol.

It is applied in poultices and washes to treat fractures.

In decoction with doradilla, it relieves body aches. In a bath, to take out the "air" that makes the joints hurt. To relieve osteoarthritis. 
Table 1: (Continued)

\begin{tabular}{|c|c|c|}
\hline $\begin{array}{l}\text { Family } \\
\text { Species (Voucher) }\end{array}$ & Vernacular name & Recipes \\
\hline
\end{tabular}

EQUISETACEAE

Equisetum giganteum L (GJM cola de caballo 1038)

\section{EUPHORBIACEAE}

Croton lachnostachyus Baill. tinajera (GJM 894)

Croton lanatus Lam. var. lorentzii (Müll. Arg.) P.E. Berry (GJM 1025)

Euphorbia eichleri Müll. Arg. golondrina (GJM 1287)

Jatropha macrocarpa Griseb. piñón, higuera del zorro

Ricinus communis L. (GJM tártago

1512)

FABACEAE

Anadenanthera colubrina cebil

(Vell.) Brenan var. cebil

(Griseb.) Altschul (GJM 1190)

Bauhinia forficata Link ssp. pezuña de vaca, uña de pruinosa (Vogel) Fortunato \& vaca

Wunderlin (GJM 923)

Caesalpinia gilliesii (Wall. ex mal de ojo

Hook.) D. Dietr. (GJM 1238)

Cercidium praecox (Ruiz \&

Pav. ex Hook.) Harms (GJM

1220)

Enterolobium contortisiliquum pacará

(Vell.) Morong (GJM 1240)

Geoffroea decorticans (Gillies chañar

ex Hook. \& Arn.) Burkart (GJM 1237)

(NDJE 2218)

With sombra de toro and zarzaparrilla, a fresh decoction is prepared and drunk to improve blood circulation. With zarzaparrilla, it is considered as being good for heart conditions. In decoction, it is used as a blood purifier. It can be combined with molle de beber and sombra de toro.

An infusion of poleo, corn silk, and cola de caballo is prepared to deflate the abdomen.

As an infusion, it is drunk for urinary infections.

The infusion of the entire plant is used for kidney stones.

Infusion or decoction is drunk for prostate conditions.

It is taken as a decocted or fresh beverage for the kidneys and kidney stones.

A leaf is put on the embers with a little altea ointment and then placed in the ear canal. The dry incinerated leaves are perfumed to get rid of the "air" that produces eye conditions (tears, conjunctivitis and eye pain.)

The decoction of its leaves is applied in washes as an antiseptic against ant bites.

The decoction of its leaves is applied in washes for skin blemishes.

The decoction of its leaves is applied in washes as wound healers.

A leaf is cut and placed in the ear to take the "air" out when there is pain.

Decoction of its leaves is applied to deflate and relieve leg pains.

The decoction is applied in washes on the head.

The decoction of its aerial part is used in washes as a wound healer and drier.

Latex is applied for the treatment of warts.

The decoction of its fruits and seeds is a drastic purgative.

To relieve swollen glands in the neck or mumps, a leaf neckless is prepared and left hanging until it dries. As it dries, the disease improves.

An informant remembers an anecdote in which he was attacked by a peccary when he put his hand in its cave, and he managed to heal the wound with a ground piece of cebil bark.

As a fresh decoction, it is used for kidney conditions.

A decoction of 3 leaves in 2 liters of pezuña de vaca water is prescribed to treat cases of diabetes. It is also combined with quiebrarado root and níspero leaves or with higuera negra leaves.

As an infusion or in mate, it relieves gallstones.

$\mathrm{H}$ is mother would advise an informant not to approach or touch it because it affects the eyesight.

The decoction of the bark is used for respiratory conditions.

The ground fruits are applied in soapy water for dandruff.

The fruit syrup is prescribed for sore throats on an empty stomach and before sleeping. The chañar fruit syrup is used for bronchial and pulmonary conditions such as bronchitis and asthma.

The decoction of the bark relieves cough. In addition, the infusion of the flowers and bark with toasted naranja peel or as a homemade remedy are expectorant. Moreover, an expectorant syrup is prepared as a homemade remedy with níspero leaves, chañar bark, quimpe, honey, and limón.

The consumption of tender alfa is prescribed as an aphrodisiac.

The infusion of tender alfa or its consumption in salads is used for prostate conditions. Tender alfa water is prescribed for its slimming properties. 1531) poroto boca negra o poroto A poultice is prepared with a coco leaf, poroto blanco o boca negra, and egg (it gets a hard blanco texture) to apply when there is fluid, or the knees or elbows are swollen. Furthermore, for fractures, patches of porotos with eggs are prepared.

Prosopis nigra (Griseb.) algarrobos Hieron. var. nigra A fresh drink is prepared by making an infusion with its ground fruits and setting it aside for cooling; the resulting preparation provides great "vitality" and energy.

For venereal conditions, a milled paste is applied as a cream of mistol and algarrobo leaves. The resin or "droplet" that comes out when the algarrobo tree is axed is applied to treat eye conditions.

An infusion of the root is drunk to treat diarrhea. An infusion is prepared with guaycurú to treat asthma.
Prosopis strombulifera (Lam.) mastuerzo Benth. var. strombulifera (GJM 34) 
Table 1: (Continued)

\begin{tabular}{ll}
\hline Family & Vernacular name \\
Species (Voucher) &
\end{tabular}

Senna cf. aphylla (Cav.) H.S. Retama

Irwin \& Barneby

Senna corymbosa (Lam.) H.S. sen

Irwin \& Barneby (GJM 1396)

Senna morongii (Britton) H.S. café del zorro

Irwin \& Barneby (GJM 1392)

Vachellia aroma (Gillies ex tusquilla, algarrobilla, Hook. \& Arn.) Seigler \& tusca

Ebinger (GJM 1298) tusca
Vachellia caven (Molina)

Seigler \& Ebinger (GJM 1297)

churquí, tusca

Seigler \& Ebinger (GJM 1297$)$

It is used as a tonic and for blood conditions.

The infusion of its leaves is drunk for upset stomachs.

The infusion of 2 or 3 leaves of sen with 3 drops of limón is a good laxative and is used to treat upset stomachs..

Washes with water and salt are applied to treat wounds and injuries and relieve foot and hand conditions.

The leaves help normalize pressure in the head, which relieves dizziness.

Tusca water is used for the treatment of pimples.

It is applied in washes with llantén to heal ulcers, varicose veins and treat pimples. An informant from Ancasti highlights the properties of tusca as follows: "A man had cut both legs due to diabetes and had brought him with oceans of pus and infection. The old man boiled tusca, strained it and put it on the legs, and it sucked his infection. The doctor couldn't explain how he had been healed." In relation to its use, they have also told him that it is a secant and that is why it affects the kidneys, so, it is not recommended for eating, but only for external use.

It is drunk alone for cough or with honey. An informant from Santa Gertrudis provides the following recipe: The algarrobilla is used on the embers, it is ground and boiled with food and honey laurel, with naranja peel.

It is considered a fresh plant, which, as an infusion and in sitz baths with malva, relieves female inflammations.

A decoction or infusion with mate is prepared in water with tusca leaves to treat acidity.

It is taken for stomach wounds; it is a natural disinfectant.

The infusion of its segments is drunk as an antidiabetic.

The infusion of its segments is taken as a purifier.

The decoction in washes is applied for eye conditions.

Taking sitz baths or drinking an infusion with it helps to urinate and relieves cystitis.

The decoction of its leaves is applied in sitz baths to relieve inflammation of the lower belly.

The infusion of tusca leaves is used for dermal purposes.

A decoction or tusca water and dry pig fat (the result looks like a soap or rubber) is prepared and applied in insect bites. The decoction of tusca leaves disinfects and relieves tick bites.

The water of tusca leaves is used for the treatment of pimples.

The decoction of its leaves is used as a disinfectant and healer; it also applied to the feet and legs for burning and blemishes. An informant combined white soap, with tusca water and pharmacy ointment to treat blemishes and burning in legs.

The decoction of its leaves is used to treat gallstones.

The decoction of its leaves alone or in mate is used to treat gastritis.

A llatén and tusca mixture relieves intestinal infections, since they are an antibiotic. It works very well as a natural disinfectant; some twigs are boiled and then drunk for stomach wounds.

A remedy with tusca, sauce and molle de beber is prepared for headaches.

Malva and jarilla is added to deflate bruises or bumps.

Not collected garabato blanco

Cfr. Senegalia praecox

Ground pieces of garbato blanco bark is applied as a healer.

Gentianella multicaulis (Gillies nencia As an infusion, it is prescribed for the liver and diabetes.

ex Griseb.) Fabris

ILLICIACEAE

Illicium verum Hook. F. anís estrellado

JUGLANDACEAE

Juglans australis Griseb. (GJM nogal, nogal cimarrón 1046)

Juglans regia L.

nogal

LAMIACEAE

Clinopodium nepeta (L.) Kuntze menta peperina

(GJM 1364)
As an infusion, it is a carminative.

The decoction of its leaves is used in washes for hair treatment.

Mate with peeled walnuts is drunk for a couple of days to boost milk production; chicken fat is also applied to cure infections.

The intake of walnuts is a memory booster.

The infusion of the fruit bark is used to treat diabetes.

The decoction of its leaves and fruits is used to treat greasy hair and cover gray hair.

It is drunk as a fresh beverage, in tea or mate to relieve gastritis.

The infusion of its leaves is drunk in mate as a digestive.

The infusion of peperina, menta and ortiga is consumed as a sedative.

As an infusion, it is a digestive. Craftspeople prepare composite yerba with naranja peel, poleo, palo amarillo and burrito. 
Table 1: (Continued)

\begin{tabular}{ll}
\hline Family & Vernacular name \\
Species (Voucher) & Recipes \\
\hline
\end{tabular}

Hedeoma multiflora Benth. tomillo As an infusion, it is considered an aphrodisiac.

(GJM 1257)

Lavandula spp.

alhucema

Leonurus japonicus Houtt. marihuanilla

(GJM 1443)

Marrubium vulgare L. (GJM

1026)

Melissa officinalis L. (GJM toronjil, melisa 1395)

Mentha sp.

yerba buena

Mentha spp. (GJM 1042, menta 919,954)

Ocimum basilicum L.

albahaca

Origanum vulgare $\mathrm{L}$.

orégano

Plectranthus sp. (GJM 1520) sertal, buscapina Rosmarinus officinalis $\mathrm{L}$.
It is prescribed as an infusion for menstrual cramps and bleeding.

For cases of influenza, a tomillo tea is prescribed.

With mate, it has a good flavor and is used as a digestive.

A pillow to rest is prepared for headaches.

An infusion of doradilla and alhucema is prescribed for menstrual cramps and bleeding; also, to relieve the belly infections of pregnant women when they sit on something hot.

Children are bathed when they get ill with the "air."

A cigarette is rolled with the dry leaf and smoked by perfuming the inside of the ear three

times; the ear is then covered with a piece of cotton.

Some residents report that, due to the similarity of its leaves with those of marijuana, it can be used as a substitute.

An infusion of the plant is applied in washes with vinegar to fight against lice.

It is ingested as an infusion to treat diabetes.

A decoction with its leaves and roasted sugar is prepared and drunk for liver infections. They are recommended for drinkers.

As an infusion, it is used as an antidepressant.

The decoction is applied in washes to treat the effects of the "air."

The infusion of its leaves is drunk for heart problems, palpitations and tachycardia.

It is prepared as an infusion or in decoction to relieve headaches.

For insomnia and the heart, the infusion of its leaves is drunk without sugar.

As an infusion or in mate, it is a digestive; it can be combined with burro, menta, toronjil, ruda and poleo.

An infusion of its leaves is prescribed as a sedative, alone or in combination with peperina and ortiga. In decoction with yerba de pollo root, menta leaves and malva leaves, it is used for constipation. As an infusion with burro, toronjil, poleo and ruda macho, it works as digestive. Also, with menta. It is a sedative.

An albahaca seed is applied in a beaten eye or with "clouds;" the cloud clears, and the seed comes out white.

The mouth is rinsed out with salt and orégano to treat oral conditions.

To relieve belly infections, it is consumed as an infusion only, or with a paico or ruda.

A diet of chicken soup with orégano is prescribed for an appropriate postpartum recovery.

In decoction with hinojo, it is drunk to relieve menstrual cramps; also, to release the retained placenta.

A tea with orégano, apio, té de burro, and poleo is prepared "correct" the stomach. Also, to relieve intestinal infections with hinojo, orégano and apio.

An orégano tea is prepared in cases of fever; 3 sips of soup are taken.

As an infusion or as a fresh beverage, it used for liver conditions.

Yerba mate, romero and beeswax (Plebeia molesta) are used with it for perfuming in the case of measles.

For cases of confinement (the placenta is not eliminated,) a homemade remedy with poleo, paico, romero and toasted cilantro seeds is prescribed.

Children are bathed with ruda and romero water, so that they don't get "aired," thus, preventing diseases.

As an infusion with apio and paico, it is taken as a blood purifier.

The infusion is a digestive.

To relieve stomach discomfort when they catch "steams."

Its infusion is taken as a sedative.

Macerated in wine, it is a stimulator, makes individuals perspire, is uplifting and helps to recover from flu states.

A mixture of wine, limón and romero that is "hot" is prepared; it makes individuals perspire and relieves their colds. It also gets people drunk. Another recipe says that boiling romero in red wine relieves the flu.

The maceration in alcohol of pita and romero leaves is used to treat rheumatism.

The decoction is applied in warm baths for body aches; the steam is stepped on when it comes to foot pain.

With a piece of alcanfor, it is applied with a cotton on the ear. Also, as a perfume with romero and alcanfor, or alcafor and romerillo.

Aguardiante liquor, alcanfor bread, ruda and romero are mixed; this is then stored in glass bottles and applied in frictions in cases of facial paralysis; this relieves the "airs." It is also perfumed with pig manure.

In alcohol, seven things are prepared to make frictions: ruda, alcanfor, romero, aspirin, aloe vera, among others.

The seeds are used to treat cholesterol. This plant is purchased in stores. 
Table 1: (Continued)

\begin{tabular}{|c|c|c|}
\hline $\begin{array}{l}\text { Family } \\
\text { Species (Voucher) }\end{array}$ & Vernacular name & Recipes \\
\hline $\begin{array}{l}\text { Salvia microphylla Kunth } \\
\text { (GJM 1051) }\end{array}$ & $\begin{array}{l}\text { fernet, coramina, } \\
\text { coronaria }\end{array}$ & $\begin{array}{l}\text { The infusion of its leaves is prescribed for hypertension. } \\
\text { The leaves are used in mate for heart conditions. The name of the plant is derived from the } \\
\text { belief that the commercial remedy known as Coramina is extracted from this plant. } \\
\text { The infusion is used as a digestive and a hepatic agent. }\end{array}$ \\
\hline $\begin{array}{l}\text { Salvia officinalis L. } \\
\text { (GJM 1503) }\end{array}$ & boldo de jardín & $\begin{array}{l}\text { As an infusion with carqueja pispa, it relieves bone pain. } \\
\text { As an infusion, it is a digestive. } \\
\text { It is drunk in a tea as a hepatic agent. People believe that it is the same species that comes } \\
\text { milled in tea bags ( } P \text { eumus boldus) }\end{array}$ \\
\hline
\end{tabular}

\section{LAURACEAE}

Cinnamomum verum J.Presl canela

Milk with canela bark is prescribed for whooping cough. Additionally, for neonates' phlegm, it is prepared with a burned coal in sugar.

Milk with canela is prepared and drunk hot, so as to not come down with measles; it can also be combined with granada husk or with a ruda leaf. For measles, a tea with canela is prescribed, and using pig manure and champa fruit from a growing stream with it for perfuming are also prescribed

Laurus nobilis L. Iaurel de cocina The infusion regularizes pressure.

The decoction of its leaves with honey is drunk to treat asthma. A decoction of milk with laurel is prepared to relieve coughing. Moreover, a decoction with the algarrobilla fruit on the embers and ground is prepared with a laurel leaf and honey with naranja peel.

Persea americana Mill. palta The decoction of palta leaves is drunk to relieve vertigo.

Boiled avocado leaf water is prepared and mixed with a paste made with toasted flour. This preparation stops diarrhea and serves to relieve dysentery and bloody diarrhea.

LILIACEAE

Aloe spp.

aloe, aloe vera

Its mucilage is used to heal canker sores and mouth sores.

For toothaches, a piece of the leaf is applied on the affected site.

In alcohol, seven things are prepared to make frictions, relieve flu and "joint pain:" ruda, alcanfor, romero, aspirin, aloe vera, among others.

The leaves are applied to relieve bumps. Also, for the "joint pain" with the mixed used to treat the flu.

A smoothie is prepared with its mucilage and honey to treat gallstones.

A smoothie of the leaf with honey or a maceration of the leaf in water is prepared during the night, and they is drunk for liver conditions.

Its leaves are ingested for the stomach and even for cancer.

Aloe vera is added to mate for the injured stomach, or the mucilage is ingested (there are

two kinds: one with a narrow leaf, and the other with a pink flower.)

They are spread on varicose legs are to produce relief.

It is made into a smoothie for kidney conditions.

The leaves are applied topically for pruritus.

The topical application of the leaves is used to treat skin fungi.

Its leaves are applied topically for dermal purposes.

Its leaves are applied to treat skin blemishes. See recipe for mixed cream in jarilla.

A smoothie with honey is prepared for healing in cases of burns. Aloe that grows in the shade, not in the sun, should be used.

LINACEAE

Linum usitatissimum L. Iino

For intestinal parasites, an anthelmintic mixture of $50 \mathrm{~g}$ of clavo de olor and $200 \mathrm{~g}$ of mixed lino seeds is prepared, and a tablespoon of tea in water or milk is ingested.

The infusion of lino seeds is used as a laxative.

LOASACEAE

Caiophora lateritia Klotzsch

(GJM 1317)

ortiga, rupa chico guiador, A decoction of the aerial part is drunk to relieve varicose veins.

ortiga guiadora The decoction is used in washes to boost hair growth and softness.

The skin is "punished" to relieve rheumatic hand pain.

It is taken with water as a sedative to treat nervousness.

LORANTHACEAE

Ligaria cuneifolia (Ruiz \& Pav.) liga chañar, lliga de tala, It is taken as an infusion or decoction of its aerial part and works as a diuretic to treat Tiegh. (GJM 1283) liga hypertension.

A liga poultice is prepared, and a porous patch is also applied for cases of fractures.

The decoction of its leaves is drunk to fight against varicose veins.

The infusion is taken as a blood purifier.

It is considered to have the property of "slimming" the blood and boosting circulation, which decreases cholesterol.

The liga del tala is good for regularizing blood pressure. It can be combined with molle and sombra de toro leaves.

It is ground in a mortar and applied as a poultice for fractures. 
Table 1: (Continued)

\begin{tabular}{ll}
\hline Family & Vernacular name \\
Species (Voucher) & \\
\hline Struthanthus uraguensis liga \\
(Hook. \& Arn.) G. Don (GJM \\
1241) \\
LYTHRACEAE \\
Heimia salicifolia (Kunth) Link arupaco, quiebraarado \\
(GJM 855)
\end{tabular}

Punica granatum L. granada

\section{MALVACEAE}

Althaea officinalis L. Ceiba chodatii (Hassl.)

Ravenna (GJM 1192)

Sphaeralcea bonariensis (Cav.) malva, malva blanca Griseb. (GJ M 854)

\section{Recipes}

The infusion is drunk to regularize blood pressure.

The infusion of the root is drunk as an antidiarrheal.

The decoction of the root is drunk as a fresh beverage for diabetes, either alone or in combination with uña de vaca and níspero leaves.

With ground and toasted roots, an infusion is prepared for diarrhea. For the same purpose, a tea is prepared with its root and milk, and some flour is added. Its root is incinerated with granada husk and some flour, and a decoction is prepared for diarrhea.

A tea is prescribed for profuse gynecologic hemorrhages.

Boiled milk with canela and granada husk is drunk for measles.

The granada peel husk is prepared in milk or is toasted with flour as an antidiarrheal. It is also prepared in a decoction with terebinto leaves and burnt sugar in coals.

The altea ointment relieves abdominal pains.

The infused flowers are drunk for heart conditions.

Enemas are prepared with malva in boiled water, oil or milk, and also in sitz baths for constipation.

To treat mouth sores and ulcers, malva water washes are applied.

For constipation, an enema made from a decoction of malva blanca with vegetable oil is applied.

A decoction of 3 malva buds, 3 tala shoots, and 3 vid tendrils is prepared to treat diarrhea. An enema with vegetable oil is applied for cases of bloody diarrhea.

In decoction with quiyocisa, it is used in washes for eye conditions.

The decoction of menta, malva and yerba de pollo root is used for constipation.

The infusion of its leaves is used to relieve fever.

The decoction of its leaves is drunk for prostate conditions.

The malva root is used as an infusion or on the embers to deflate the lower belly and urinary tract, when infections occur due to the heat that make it difficult to urinate. It is considered to be a plant with "a lot of mystery" or healing power; and thus, it is used in doses of three elements or parts.

It is applied in sitz baths to deflate the belly, with root and/or leaf washes. For bowel pain, constipation and infections. In mystery: chamico, hinojo and malva are boiled, and twigs are added; it is prepared for a sitz bath when a child's body temperature rises (because he/she has sat on very hot ground.) It can also be combined with membrillo or paico leaves.

Water is drunk to relieve gas.

The leaves are boiled in water, and $1 / 2$ liters of milk are added to treat the upset stomachs. To deflate the stomach, a segment is prepared in 1 liter of water, then it is set aside, strained and drunk fresh. A kind of chuño of malva is prepared by boiling the malva root with milk to give to the children.

Water sitz baths are applied with 20-liter containers for pregnancy care, as an antispasmodic.

A midwife from Santa Gertrudis, would prescribe neonates tala and malva water with honeycomb or queyita to get rid of the phlegm that could have been accumulated in the airways.

The decoction of its leaves is drunk to relieve menstrual cramps.

It is applied in sitz baths to treat female infections.

In sitz baths, to relieve the "heat in your behind" and hemorrhoids; either alone or with hediondilla.

A cataplasm of malva leaves is applied on the forehead and head to relieve headaches.

With jarilla and tusca, for bruises or bumps. 
Table 1: (Continued)

\begin{tabular}{|c|c|c|}
\hline $\begin{array}{l}\text { Family } \\
\text { Species (Voucher) }\end{array}$ & Vernacular name & Recipes \\
\hline Melia azedarach L. & paraíso & $\begin{array}{l}\text { Its fruits are used in washes for treating dandruff and seborrhea. } \\
\text { Its fruits are used in washes to relieve headaches. } \\
\text { Inhaling a decoction of the fruits, so that colds and sinusitis "ripen" and improve, is } \\
\text { prescribed. Eleven dried fruits and } 30 \text { seconds of steam inhalation twice a day are } \\
\text { prescribed. Despite this, it is considered a risky practice due to the toxicity of the fruit. } \\
\text { Roasted dried fruits are prepared with honey and canela, which are then drunk in small } \\
\text { quantities as a vermifuge. } \\
\text { The decoction of its fruits is used in washes to treat fleas. } \\
\text { The decoction of its fruits is used in washes to treat pediculosis. Additionally, a maceration in } \\
\text { alcohol can also be employed. }\end{array}$ \\
\hline
\end{tabular}

\section{MONIMIACEAE}

Peumus boldus Molina MORACEAE

Ficus carica L. (GJM 1100)

boldo

Higuera, higuera blanca, Higuera negra

\author{
MYRTACEAE \\ Eucalyptus sp. \\ Syzygium aromaticum (L.) clavo de olor \\ Merr. \& L.M.Perry \\ NYCTAGINACEAE \\ Bougainvillea stipitata Griseb espinilllo \\ (GJM 896) \\ OLEACEAE \\ Olea europaea L. \\ olivo \\ OXALIDACEAE \\ Oxalis conorrhiza Jacq. (GJM vinagrillo \\ 1258) \\ PAPAVERACEAE \\ Argemone subfusiformis G.B. cardosanto \\ Ownbey (GJM 903) \\ eucalipto

cardosanto

\section{PASSIFLORACEAE}

Passiflora caerulea L. PHYTOLACCACEAE Petiveria alliacea L. var. alliacea (GJM 1423) PINACEAE Pinus sp. pasionaria

calauchín pino
The commercial preparation is drunk as a tea to relieve vomiting.

In cases of asthma, coffee with chicken fat and dried figs on an empty stomach for three days is prescribed.

Eating dried figs in water during the morning on an empty stomach for constipation is prescribed.

The higuera grabs the "air;" one takes the air from the stream or plants such as the higuera. The higuera is annoying for some individuals, especially the city slickers who do not know about it.

A decoction with its leaves is prepared and toasted and well dried flour is added until it is kind of thick; it should be done with the big higo blanco, not the cuello one.

The water of higuera leaves and lechuga leaves are combined to regulate blood pressure.

A fresh decoction of its leaves is drunk as a fresh beverage to treat diabetes. For the same purpose, it is prepared as an infusion with malfato leaves or pezuña de vaca leaves.

It is used in ritual cure to treat umbilical herniation. This is done by curing the trail on the bark of the higuera negra, marking it with a knife, and hanging it on top of a bonfire; when it dries, it means that the navel "was tucked in," and the hernia healed.

A fig is cut and put in the pocket to cure hemorrhoids.

A fig, sugar and honey syrup is prepared and taken on an empty stomach every day to relieve asthma symptoms.

The steam of its leaves is inhaled as an antiasthmatic agent.

Steam from its boiled leaves is inhaled as a decongestant. Steam from the round-leaf silver eucaliptus (E. cinerea) is preferred.

For intestinal parasites, an anthelmintic mixture of $50 \mathrm{~g}$ of clavo de olor and $200 \mathrm{~g}$ of mixed lino seeds is prepared, and a tablespoon of tea in water or milk is ingested.

A clavo de olor is bitten to relieve tooth aches.

A tea with incayuyo, salvia de la Puna, vira vira, and espinillo is prepared for liver conditions.

The infusion of its leaves is drunk to treat nervousness.

An infusion of 3 to 7 olive leaves is used to treat high blood pressure; it should not be used excessively because it is strong.

It is put on the teeth to whiten them; it tastes sour.

The boiled root is used for washes in order to relieve molle or quebracho "stings."

A decoction of its seeds is applied as washes to relieve eye conditions.

The infusion of its leaves is used for the blood to "slim," so, it is likely to have cholesterollowering effects.

Latex is applied in poison or insect and spider bites, as an alexiteric and anti- inflammatory. It is also boiled in water for the poison or irritation in the baby's butt.

The infusion of its leaves regularizes blood pressure imbalances.

A calauchín leaf is rolled up and placed in the ear canal for ear pain.

The pino shoot (brachyblast) boiled with wine is drunk to treat coughing. 
Table 1: (Continued)

\begin{tabular}{|c|c|c|}
\hline $\begin{array}{l}\text { Family } \\
\text { Species (Voucher) }\end{array}$ & Vernacular name & Recipes \\
\hline PIPERACEAE & & \\
\hline $\begin{array}{l}\text { Piper nigrum L. } \\
\text { PLANTAG INACEAE }\end{array}$ & pimienta & Is applied topically to the woman's chest to wean children. \\
\hline Plantago major $\mathrm{L}$. & llantén & $\begin{array}{l}\text { To relieve menstrual cramps, an infusion of llantén leaves is prescribed. } \\
\text { The decoction of its leaves is drunk for female infections. } \\
\text { Washes with a maceration in alcohol made of romero, llantén, aloe, ruda, aspirin, and } \\
\text { alcanfor (seven things or herbs in total) are applied to relieve pain from ankle strains or } \\
\text { sprains. Also, for foot pains. } \\
\text { It is combined with tusca water and applied in washes to heal ulcers. It can also be applied } \\
\text { as a poultice. } \\
\text { It is recommended to drink wide-leaf Ilantén as a fresh beverage (in decoction) to relieve fever. } \\
\text { The leaves are applied in warm oil to relieve infections or insect bites. } \\
\text { Warm leaves are applied to treat pimples and boils, which relieves inflammation; also, for } \\
\text { pimples from eruptive diseases. It is also used in decoction with tusca leaves. } \\
\text { It is applied in cataplasms with altea ointment to treat mumps. } \\
\text { An infusion of } 3-4 \text { leaves in gargles for a sore throat is applied. It is also prepared with hot } \\
\text { water, limón and baking soda. } \\
\text { It is applied in infections such as canker sores. } \\
\text { As an infusion, it is good for the stomach, either alone or with sombra de toro. } \\
\text { As an infusion, it is used for gastritis. } \\
\text { It is applied in sitz baths to relieve hemorrhoids. }\end{array}$ \\
\hline Plantago sp. & Ilantén peludito & A llantén and tusca mixture relieves intestinal infections, since it works as an antibiotic. \\
\hline
\end{tabular}

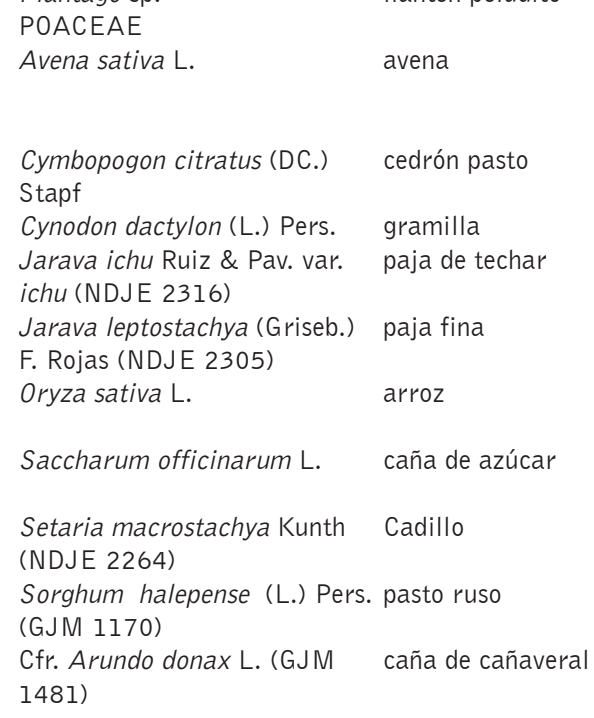

Zea mays L. maíz

\section{POLYGONACEAE}

Rheum sp. ruibarbo

PTERIDACEAE

Adiantum lorentzii Hieron. helecho palo negro,

(GJM 1376)

RANUNCULACEAE

Clematis montevidensis barba de chivo

Spreng. var. denticulata (Vell.)

Bacigalupo (GJM 1233)
For cases of constipation, "avena water" is prescribed.

An informant recalls a cream of jarilla, aloe vera, avena, olive oil and beeswax that craftspeople made to treat skin blemishes.

As an infusion, it is prescribed for heart conditions.

As an infusion, either alone or with yerba mate, it is a digestive.

The infusion or decoction of its root is taken as a purifier to treat kidney conditions and stones.

A neckless for snake bites is applied.

Some paja is applied on the snake bite.

The boiled root is applied for hair care and growth

Rice water is prescribed for diarrhea.

Rice water or raw rice is consumed to treat gastritis.

Symbolic use: A caña de azúcar is placed under the diabetic's mattress, and, as it dries, the person heals, and the blood sugar level is reduced

Its thorns are the cause of warts.

As an infusion, it helps with deliveries and to overcome postpartum hemorrhages.

Ashes are applied in areas affected by eczema.

An infusion of the root is used as an alexiteric to counteract snake bites.

The decoction of caña roots is used in washes to treat alopecia.

The caña is split, an "inner cap" is taken out, and set aside to dry as an adhesive that is applied as a healer nd for the treatment of burns.

In a mazamorra dish with water, it is used to boost breast milk production.

Symbolic action: Three maíz kernels are applied to warts, and 3 signs of the cross are made; the kernels are tied in a handkerchief and thrown backwards without turning; the person who picks up the handkerchief will get warts. It is also customary to thrust the tip of the grain into the warts by marking a cross, and then throwing the fruit at a crossroads. Infusion with corn silk is used to lower blood pressure.

An infusion of poleo, corn silk, and cola de caballo is prepared to deflate the abdomen.

The infusion of the corn silk is used as a diuretic.

Nine grains of boiled red maíz in 1 liter of water are prescribed to treat pneumonia.

The decoction of its leaves is taken as a decongestant.

It is toxic and dangerous to health; the effects are not well known.

The perfumed flower is used to relieve earaches.

The perfumed flower for when the eyes are tearful or when they burn.

To treat odontalgia, a liana is tied around the hand, and this produces blisters, which relieve the toothache. However, it should not be used in large quantities. 
Table 1: (Continued)

\begin{tabular}{ll} 
Family & Vernacular name \\
Species (Voucher) & \\
\hline RHAMNACEAE
\end{tabular}

RHAMNACEAE

Colletia spinosissima J.F. Gmel.tola, tola tola (NDJE 2007)

Ziziphus mistol Griseb. (GJM mistol 944)

ROSACEAE

Cydonia oblonga Miller (GJM membrillo 1101)

Eriobotrya japonica (Thunb.) níspero Lindl.

$\begin{array}{ll}\text { Malus domestica Borkh. } & \text { manzano } \\ \begin{array}{l}\text { Prunus domestica L. } \\ \text { Prunus persica (L.) Batsch }\end{array} & \begin{array}{l}\text { ciruela } \\ \text { durazno, durazno }\end{array} \\ & \\ \text { Rosa sp. } & \text { rosa de jardín } \\ \text { Rosa sp. } & \text { rosa de octubre } \\ \text { RUTACEAE } & \\ \text { Citrus reticulata Blanco } & \text { mandarino }\end{array}$

Citrus $\times$ aurantium $\mathrm{L} . \quad$ naranjo amargo

Citrus $\times$ limon (L.) Burm.f. limón
Antiseptic against ant bites

The decoction of its aerial part is applied in head washes for good hair quality and for treating dandruff and alopecia.

Its fruits ground with the seed in boiled and then strained water are ingested as a refreshing and energizing drink. It is also prepared by boiling it with milk. It is considered to work well for sight, bones, and intelligence ("it wakes up the mind.")

For venereal conditions, a milled paste is applied as a cream of mistol and algarrobo leaves.

In water, to lower cholesterol

In water, to treat uric acid

The infusion of its leaves with malva leaves or root is used to deflate the intestine.

A tea with membrillo leaves is prepared, and toasted flour is added. A mixture of 3 herbs is prepared: membrillo, piscoyuyo, and molle pispo. It can also be prepared as an infusion with membrillo and níspero leaves. As a "mystery," 3 membrillo leaves and 3 álamo leaves are mixed.

The infusion of its leaves with those of uña de vaca and quiebraarado root is used for diabetes.

An infusion of membrillo leaves and níspero is combined for diarrhea. They can also be used alone.

The infusion of its leaves as a syrup with burnt sugar is used as a cough suppressant. With the same use, it is combined with higuera negra leaves or with salvia blanca leaves. Moreover, an expectorant syrup is prepared as a homemade remedy with níspero leaves, chañar bark, quimpe, honey, and limón.

Apple intake is a memory booster.

The infusion of its inflorescences is used for children as sedatives.

The ciruela compote has laxative effects.

o In particular, the durazno amarillo leaf is used. It is hepatic and relieves the stomach, especially in cases of hangovers.

A bitter water is prepared with the leaves, which are drunk for headaches due to excess wine. An infusion with its leaves alone or with manzanilla amarga or boliviana leaves is prescribed for flatulence.

A leaf tea is drunk for relief when you have drunk alcohol.

The infusion of the leaves is drunk for heart conditions.

An infusion of these flowers is used to treat hypertension.

The decoction of its flower is a carminative.

A rosa de octubre petal tea (it only blooms once) is indicated as a digestive for babies.

The decoction in tea or mate, or the fruit peel is taken as a sedative. Some informants remember that, when someone died, they would make mandarino tea cups to sedate the mourners in the wake.

Its leaves are used in mate for sharp pains in the heart.

The infusion of its leaves is used for heart conditions.

The zest of its peel dissolved in water is used in washes to stop hair loss.

Washes with its juice are applied to treat dandruff.

The craftspeople would make composite yerba with poleo, burrito and peperina.

Warm limón is rubbed as a poultice in areas with joint pain.

It is boiled with salt and vinegar, and set aside to cool; it is then applied with pieces of cloth on the back, throat and chest to relieve fever. It can also be used with ruda leaves.

Its juice is considered to have slimming properties.

It is prescribed with baking soda for flatulence.

Three drops with 2 or 3 leaves of sen are drunk for cases of constipation.

It is squeezed, and 3 eggs are then covered with the juice; the preparation moves on an empty stomach, and the bitter liquid that comes from the dissolution of the eggshell is drunk. Its juice is also prescribed on an empty stomach for 7 seven days, or with honey to dissolve gallstones.

The craftspeople prepare a deodorant and repellent cream with baking soda, beeswax, clavo de olor and limón peel.

To relieve sore throats, gargles with its juice, baking soda or swarm honey are made.

Its seed is applied on the face to relieve toothaches.

The incinerated seed is applied in the ear canal to relieve ear pain.

A mixture of wine, limón and romero that is "hot" is prepared; it makes individuals perspire and relieves their colds. It also gets people drunk. With honey, it is a cold decongestant. Its leaves in mate are a digestive. 
Table 1: (Continued)

\begin{tabular}{lll}
\hline Family & Vernacular name & Recipes \\
Species (Voucher) & & \\
\hline Citrus $x$ sinensis Osbeck & naranjo & For constipation, naranja juice is drunk on an empty stomach alone or with honey \\
& & In a digestive mixture of composite yerba with poleo, té de burro, peperina and palo
\end{tabular}

In a digestive mixture of composite yerba with poleo, té de burro, peperina and palo amarillo.

For bronchial conditions, a honey syrup with toasted naranja peel and a jarilla sprig is prepared.

As an infusion with quimpe, or with flowers and chañar bark, it is taken as a cough suppressant. With cebolla peel and toasted naranja peel. It is also prepared as an infusion with burnt sugar in coals and honey.

Ruta chalepensis L. (GJM ruda 1383)

Zanthoxylum coco Gillies ex Hook. f. \& Arn. (GJM 1266)

\section{SALICACEAE}

Populus deltoides W. Bartram álamo, álamo plateado ex Marshall

Salix humboldtiana Willd. sauce, sauce llorón (GJM 929)

\section{SCHIZAEACEAE}

Anemia tomentosa (Savigny) doradilla

Sw. var. anthriscifolia

(Schrad.) Mickel (GJM 1374)

SCROPHULARIACEAE

Buddleja mendozensis Gillies salvia blanca

ex Benth. (GJM 1273)
Ruda and vira vira washes are applied for the treatment of hives.

The infusion of ruda leaves prescribed for painful menstrual periods.

Children are bathed with ruda and romero water, so that they don't get "aired," thus, preventing diseases.

For sprains, a paste of ground goat fat, Pez de Castilla (a stone) and ruda is prepared and applied as a cataplasm.

In alcohol, seven things are prepared to make frictions: ruda, alcanfor, romero, aspirin, aloe vera, among others. It relieves the flu as well as joint and leg pains.

A leaf of ruda in milk is combined with canela, which is drunk to treat measles.

It is used in cloths with limón, salt and vinegar to relieve fever.

The plant is rubbed with the hands to relieve foot and bone pain affected by the "air." It is also applied with salt and wrapped in paper burying in embers, to remove and wrap the joints. A small piece of ruda is applied for tooth decay.

Mate or tea with milk, ruda and burnt sugar are digestive and preventive, and are recommended for the month of August. It can be combined in tea with paico. With orégano, it is used for cases of infections.

The infusion of its leaves on an empty stomach is drunk for liver conditions and headaches.

A segment is put on the embers and placed in the mouth to treat canker sores and mouth sores. Its leaves are applied on the embers by rubbing them to take out the "air" that causes ear pain. A leaf is also wrapped in cotton that is dry or moistened with alcohol and placed in the ear canal. In other cases, its combination with alcanfor is prescribed.

Aguardiante liquor, alcanfor bread, ruda and romero are mixed; this is then stored in glass bottles and applied in frictions in cases of facial paralysis; this relieves the "airs." It is also perfumed with pig manure.

An informant reports that the infusion of its leaves has antimalarial properties.

Its leaves are placed under the beds to scare away fleas.

The bitter decoction of branches and leaves is used in washes to eliminate lice.

A poultice is prepared with a coco leaf, poroto blanco o boca negra, and egg (it gets a hard texture) to apply when there is fluid, or the knees or elbows are swollen.

The decoction of its segments is used for hand and feet washing with very hot water to relieve rheumatism.

The infusion of its bark with salt is used to rinse the mouth out and make gargles for throat conditions.

To treat diarrhea, a "mystery" infusion is prepared with three álamo leaves and three membrillo leaves

It is applied in washes to relieve leg pains.

The infusion of its bark is drunk for headaches. Alone or combined with tusca and molle de beber

The decoction of its leaves in washings deflates varicose veins.

The decoction of its leaves is used in washes for dandruff and seborrhea.

The boiled leaf in water is applied in the hair to fight against hair loss.

In decoction with tramontana, it relieves body aches.

An infusion of doradilla alone or with alhucema, or with alcanfor, relieves menstrual cramps. The infusion of its fronds is drunk to relieve postpartum discomfort.

The infusion of its fronds boosts blood circulation.

The infusion of its fronds is blood purifying.

The decoction of its fronds is drunk so that the blood "slims."

The infusion of its fronds is a hepatic agent.

The infusion of its fronds is a digestive.

The infusion of its leaves whets the appetite.

The leaves are used in tea with burnt sugar or honey for coughing. Alone or in combination with molle de beber and naranja peel with toasted sugar. Also combined with níspero leaves or cebolla peel and limón peel. 
Table 1: (Continued)

\begin{tabular}{ll}
\hline Family & Vernacular name \\
Species (Voucher) & \\
\hline SOLANACEAE & Recipes
\end{tabular}

Capsicum sp.

pimentón, pimiento

Cestrum parqui L'Hér. (GJM hediondilla

864)

Datura ferox L. (GJM 1048) chamico

Lycium cestroides Schltdl.

(GJM 1060)

Nicotiana glauca Graham palán, palán-palán

(GJ M 923)

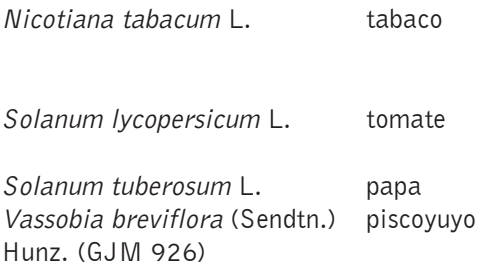

The ground pimentón in cotton stops nosebleeds.

The commercial preparation of the fruit of ground pimentón is applied to stop bleeding.

It is ground and then applied on the nipple to foster weaning.

Its leaves are applied in poultices on the temples to relieve headaches.

Its leaves are placed under the beds to scare away fleas.

To relieve stomach ache caused by heat, hediondilla (fresh plant) is applied with cold water in sitz baths.

It is used as a venous anti-inflammatory to relieve leg pain.

Clothes are washed with a soap made with hediondilla to treat hemorrhoids and as a skin healer. The leaf of this plant is also applied in underwear and the anus.

Its leaves are placed under the hat or on the neck to provide protect against sun poisoning. It is also applied in poultices with white soap.

Hediondilla water in sitz baths relieves urinary infections caused by scalds and irritations in the behind.

A segment is used in the hat to provide protection against sun poisoning, or a poultice is prepared.

Since it is fresh, "four leaves are put between the underwear and the buttocks to avoid the heat of the saddle and steam;" with iguana fat, it "sucks the dirt" from pimples and boils; it relieves itching caused by the sun heat. A segment is also used in the hat and on the saddles to take out heat.

It is applied in pimples from eruptive diseases (measles.)

Boil the leaves, then in water with salt, wash the burns.

When the eyesight hurts, a leaf is applied in the eye region.

In sitz baths, to "dissipate infections", the "internal fever that oozes" and relieve hemorrhoids.

When the eyesight hurts, a leaf is applied in the eye region.

In sitz baths, to "dissipate infections", the "internal fever that oozes" and relieve hemorrhoids.

A cigar is rolled with the leaf and flower and then smoked for the treatment of asthma. Sitz baths for bowel pain and infections. In mystery: chamico, hinojo and malva are boiled, and twigs are added; it is prepared for a sitz bath when a child's body temperature rises (because he/she has sat on very hot ground.) The combination of chamico, hinojo and apio is also indicated (it is added at the end to the decoction by squeezing some raw leaves.) It is used to treat infections.

It is applied in a cataplasm for headaches. For emergency fractures, it is reported that a poultice of ground palán with chicken fat and sheep manure, then wrapped up in a cloth, was made. The fever is relieved by applying palán leaves on the forehead.

The leaves are used to "fix the legs" and apply as them a fresh cataplasm on varicose veins. It is also useful for infections or heat in the feet, for which its leaves are applied in oil and placed in the socks to hold them.

To treat mumps, a leaf of palán with chicken fat is applied and then wrapped in a handkerchief.

In cases of conjunctivitis or bumps in the eyes or cheekbones, a piece of leaf moistened in saliva is applied around the eyes.

For the treatment of ulcers and sores, its leaves lightly roasted in chicken fat are applied. The leaves are applied to the head when there is sun poisoning, since they are considered a fresh plant.

The leaves are applied to dry pimples and boils; alone or with oil, ash, iguana or ampalagua fat, or a tallow candle.

It is used to relieve infected pimples and wounds and eruptive diseases. An informant recounts how he could take out a piquillín thorn with palán leaves in hot water and altea ointment. The infusion is used in washes as a pediculicide.

Its ash is applied to heal canker sores and mouth sores.

A cream with white soap, cigar tabaco and sugar is prepared to treat pimples. Some slices of the fruit are applied for sunburns.

Tomate puree is placed on the chest to generate apprehension and foster weaning of the child. Some papa slices with salt are placed on both sides of the temple to relieve headaches.

It relieves sores; when they turn red or hurt, the leaves are put in chicken or iguana fat, are lightly roasted, and then put as a cataplasm in the skin as hot as possible.

A mixture of 3 plants is prepared: a membrillo bud, piscoyuyo and a molle pispo bud to treat diarrhea.

To stop diarrhea, a tea is made with a little piece of it, and membrillo can also be added. 
Table 1: (Continued)

\begin{tabular}{|c|c|c|}
\hline $\begin{array}{l}\text { Family } \\
\text { Species (Voucher) }\end{array}$ & Vernacular name & Recipes \\
\hline \multicolumn{3}{|l|}{ THEACEAE } \\
\hline Camellia sinensis (L.) Kuntze & té & $\begin{array}{l}\text { Its infusion is antidiarrheal } \\
\text { Washes with it relieves eye conditions. }\end{array}$ \\
\hline \multicolumn{3}{|l|}{ TILIACEAE } \\
\hline Tilia sp. & tilo & $\begin{array}{l}\text { An infusion with manzanilla and flower bracts of tilo is prepared to remove fat. } \\
\text { The infusion of the flower bracts is a sedative. It is purchased in pharmacies. }\end{array}$ \\
\hline \multicolumn{3}{|l|}{ URTICACEAE } \\
\hline Urtica circularis (Hicken) & rupachico, ortiga & The infusion of its leaves is taken as a decongestant. \\
\hline Sorarú (GJM 1314) & & $\begin{array}{l}\text { The infusion of its leaves is drunk for its circulatory properties. } \\
\text { The infusion is drunk for coughing. } \\
\text { A decoction with the leaves is prepared to wash the feet when they are sore. } \\
\text { Water decoction is used in washes to relieve varicose veins. } \\
\text { It is applied to prevent hair loss. } \\
\text { The skin is "punished" in order to treat rheumatic hand pain. }\end{array}$ \\
\hline $\begin{array}{l}\text { Urtica urens L. } \\
\text { (GJM 1315) }\end{array}$ & ortiga & $\begin{array}{l}\text { As an infusion with menta and peperina, it is used as a sedative. } \\
\text { The root infusion is used for alopecia. } \\
\text { The craftspeople prepare it as an infusion or as part of composite yerba; it is used as a purifier. }\end{array}$ \\
\hline
\end{tabular}

\section{VERBENACEAE}

Aloysia citriodora Palau (GJM cedrón, cedrón del campo Its infusion is prescribed with menta as a postpartum sedative. 1429)

The leaves in tea or mate are digestive.

It is drunk as an infusion as a sedative.

As an infusion, it is very good for the heart, palpitations, discomfort and decay.

Aloysia gratissima (Gillies \& palo amarillo, poleo del Hook.)
Palo amarillo is used for perfuming to treat measles.

The palo amarillo water is considered an antibiotic and healer for pimples.

As an infusion with poleo, it is used to relieve vomiting.

The infusion of palo amarillo, paico and té de burro is a laxative and relieves upset stomachs. Digestive, purgative. The craftspeople make composite yerba with peperina, burrito, poleo and naranja peel.

Aloysia polystachya (Griseb.) burrito, té de burro, poleo The infusion of palo amarillo, paico and té de burro is a laxative and relieves upset stomachs. Moldenke

(GJM 1224)

Glandularia peruviana (L.) sangre de Cristo

Small (GJM 857 A)

Lippia alba (Mill.) N.E. Br. salvia lora ex Britton \& P. Wilson (GJM 1379)

Lippia integrifolia (Griseb.) incayuyo Hieron.

Lippia turbinata Griseb. (GJM poleo 1241)

Verbena intermedia Gillies \& cuadrado

Hook. ex Hook. (GJM 917)

VISCACEAE

Phoradendron liga (Gillies ex liga pispita Hook. \& Arn.) Eichler (GJM

1036)

VITACEAE

Cissus tweediana (Baker) viña del zorro

Griseb.
The infusion of its leaves is drunk to treat vomiting.

Its infusion is used for digestive and hepatic conditions (from consuming alcohol.)

The decoction of its aerial part is used to relieve belly pain.

The infusion of its leaves is prescribed for heart conditions.

A tea with molle sonso, manzanilla and salvia lora is prescribed in case of vomiting.

As an infusion, for heart conditions

As an infusion, it has digestive properties.

A decoction or infusion with mate is prepared in water with tusca leaves to treat acidity.

A tea with incayuyo, salvia de la Puna, vira vira, and espinillo (not V. caven) is prepared for liver conditions.

As an infusion (tea or mate,) it is a digestive. The pilgrims from Santiago del Estero carry it with them a lot, when they come to see the Virgin of the Valley in December.

Circulatory stimulant

As an infusion, with molle de beber and sombra de toro, it boosts blood circulation.

For cases of confinement (the placenta is not eliminated,) a homemade remedy with poleo, paico, romero and toasted cilantro seeds is prescribed.

As an infusion, it has slimming properties, either alone or in combination with corn silk and cola de caballo, which are diuretics that soften the abdomen.

As an infusion, it is an antidiarrheal.

As an infusion with palo amarillo and with a little coal in sugar, it is used to relieve vomiting. It is used as a digestive in mate or in the elaboration of craft composite yerba. Its infusion can be drunk with burro, menta, toronjil, ruda macho and yerba buena. As a tea with orégano, apio and burro.

For prostate cancer

It is used in decoction to treat hypertension.

For the circulation of blood and varicose veins

In case of snake bites, the tuber is tied or "linked" in the affected area so that the poison does not penetrate.

The tuber is used to treat cholesterol.

The tuber in water is used to treat diabetes.

A decoction as aguapasto of the root or grated tuber is drunk to deflate the prostate. 
Table 1: (Continued)

\begin{tabular}{ll}
\hline Family & Vernacular name \\
Species (Voucher) & Recipes \\
\hline
\end{tabular}

Vitis vinifera L. (GJM 1480) vid, uva, parra

Raisins or green uvas are ingested to treat constipation.

A decoction of 3 malva buds, 3 tala shoots, and 3 vid tendrils is prepared to treat diarrhea. A tea of its leaves and stems is prepared to treat high blood pressure.

The raisins fried in oil are applied hot to dry pimples. For the same purpose, raisins are used in cataplasms with sugar.

Its leaves are applied with vinegar to relieve fever.

ZYGOPHYLLACEAE

Larrea divaricata Cav. (GJM jarilla 1218)

Porlieria microphylla (Baill.) Descole, O’Donell \& Lourteig (GJM 934)

UNDETERMINED SPECIES

Undetermined; not collected

Undetermined; Not collected

Undetermined

Undetermined; Not collected

Undetermined; Not collected Undetermined; Not collected Undetermined; Not collected Undetermined; Not collected Undetermined; Not collected Undetermined; Not collected Undetermined; Not collected

Undetermined; Not collected

Undetermined; Not collected Undetermined; Not collected Undetermined; Not collected

tres caras; tres cantos uña de gato

vira vira

caspicuchara, frutilla

erespo, pan de cata apio del campo

chachacoma

helecho macho

muña, muña-muña orejita del agua

paja

penquita

romerillo, pichanilla

romerillo, pichanilla

salvia muña

salvia de la Puna

Midwives prescribed a leaf tea to speed up a delivery when it was full-term.

It is prescribed as an infusion in baths to treat hemorrhoids.

A decoction is applied to treat varicose veins.

A bitter tea of jarilla is uplifting.

An informant recalls a cream of jarilla, aloe vera, avena, olive oil and beeswax that craftspeople made to treat skin blemishes.

An infusion of the aerial part is applied in washes to treat fungi and perspiration in the feet.

An infusion of its leaves is prepared and used as eye drops for eye conditions.

Gargles are made with the infusion to relieve sore throats.

A soft infusion (a little bud in a cup) is prepared; it is then covered, and 1 or 2 grains of salt are added; after that, it is strained. A few sips should be taken for a cold to improve. It is used as a flu medicine and to fight colds. For colds, water steam with jarilla or water baths with jarilla (which is warm) are usually used for fresh conditions.

As an infusion, with 2 grains of salt, it can be drunk or used to make gargles for coughing. As an infusion with salt, it is drunk for pneumonia and lung conditions, preferably on an empty stomach. For bronchial conditions, a honey syrup with toasted naranja peel and a jarilla sprig is prepared.

Washes are applied to relieve foot pain and improve circulation.

In cases of strains or fractures, a cataplasm of ground jarilla with Pez de Castilla (a stone bought in herbal stores) and egg white is applied so that the air dries.

With malva and tusca, or in decoction with salt, for bruises, bumps, strains or sprains. With terebinto, hot poultices are prepared to treat strains and sprains Stems and leaves are used in an infusion for gallbladder treatment.

They are applied to treat infections.

The infusion is drunk as anti-asthmatic.

The infusion or decoction in water is applied to treat parasites.

It is used to treat nerves.

To treat digestive conditions

To purify the blood and treat swelling of the legs

Aphrodisiac properties are attributed.

It is used to treat colds. It grows towards the west in the Puna region.

Leaves in cataplasms

Smelling its root is prescribed to avoid or relieve the symptoms of mountain sickness.

Parts of it are peeled and broken and then applied in the region of a viper bite.

Smelling it works well for mountain sickness.

Smelling it works well for mountain sickness.

As an infusion, it is used for liver conditions.

It is a creeping herb that grows on the ground. It is used for blood conditions.

A tea with incayuyo, salvia de la Puna, vira vira, and espinillo is prepared for liver conditions. Salvia de la Puna grows on the hills of Singuil, Humaya, and El Rodeo, in the Ambato region.

suma, papa de Orazú, yaco The root is chewed as a stimulant to relieve tiredness.

The root is chewed as an anesthetic; it is "yummy and a little salty" and "buffers" the tongue.

The aerial part of the plant is boiled and drunk for prostate conditions.

Circulatory stimulant

Ruda and vira vira washes are applied for the treatment of hives.

A tea with incayuyo, salvia de la Puna, vira vira, and espinillo (not V. caven) is prepared for liver conditions.

It relieves heavy menstrual periods and postpartum bleeding. 
Table 1: (Continued)

\begin{tabular}{|c|c|c|}
\hline $\begin{array}{l}\text { Family } \\
\text { Species (Voucher) }\end{array}$ & Vernacular name & Recipes \\
\hline Undetermined; Not collected & zarzaparilla & $\begin{array}{l}\text { The infusion is drunk for muscle and joint pains. } \\
\text { It is used in the treatment of urinary infections. } \\
\text { It is used for cases of painful menstrual periods. } \\
\text { It is used as an oxytocic. } \\
\text { It is applied to treat varicose veins. } \\
\text { In fresh decoction with cola de caballo and sombra de toro, it is drunk to boost blood } \\
\text { circulation. } \\
\text { The infusion of its leaves is drunk to decrease uric acid levels. } \\
\text { The leaf and root in an infusion is blood purifying and has an impact on the "fat blood," and } \\
\text { uric acid decreases. To treat "minor urine" or difficulty urinating. }\end{array}$ \\
\hline
\end{tabular}

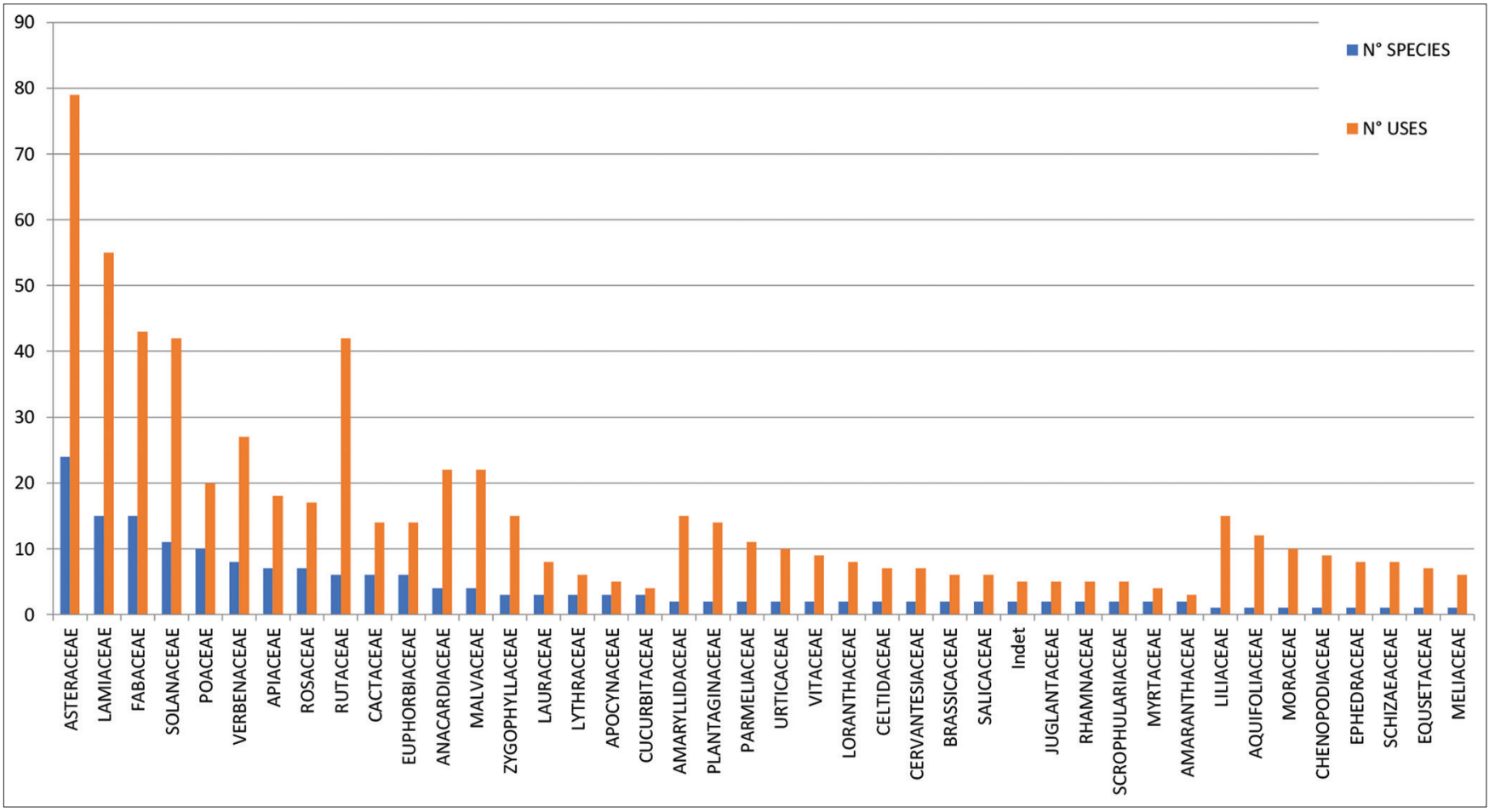

Figure 2: Arrangement of botanical families based on the number of species and medicinal uses

Lamiaceae (15 spp./55 uses), Solanaceae (11 spp./4l uses), Poaceae (10 spp./20 uses), and Verbenaceae (8 spp./27 uses). These findings were in consistence with previous reports in other parts of the world (Tabuti et al., 2003; Bolson et al., 2014; Kadir et al., 2014). Regarding the composition of the most numerous families in number of species, there is a coincidence with other natural pharmacopoeias reviewed for other countries and continents of the world (Moerman et al., 1999), accounting for the abundance of biodiversity (e.g. Asteraceae and Fabaceae) and the presence of active principles in these families (e.g. Lamiaceae and Solanaceae). The dominance of Asteraceae, Fabaceae, and Lamiaceae in the local flora facilitates a greater interaction of the local communities with them in the study area (Farooq et al., 2019). This may be due to their wide distribution of plant species belonging to Asteraceae (Barboza et al., 2006) and their traditional uses known by the indigenous communities living in different parts of the world. The traditional uses of these groups of plant families are well recognized by local inhabitants, and many of them have a variety of significant bioactive, pharmacological and organoleptic properties due to their secondary metabolites (Arias Toledo 2006; Arias Toledo et al., 2007, 2010; Lulekal et al., 2008; Martínez 2010; Baydoun et al., 2015; Qaseem et al., 2019).

\section{b) Most relevant species}

Figure 3 shows, in a descending order, the species with the greatest numbers of medicinal uses and applications. On the top of the list is Sphaeralcea bonariensis (Cav.) Griseb., followed by Aloe spp., Ruta chalepensis L., Rosmarinus officinalis L., Vachellia caven (Molina) Seigler and Ebinger, Cestrum parqui LHér., Larrea divaricata Cav., Plantago major L., and Ilex parguariensis A.St.-Hil. The various applications can be seen in the different shades of the bars, with gastroentorological and skin conditions prevailing among the species with the greatest number of uses. Among these species, a large part is 
cited as being of pharmaceutical interest due to their active ingredients and, in some cases, as coded in editions of the National Pharmacopoeia (Luján et al., 2011), such as the case of Matricaria chamomilla and Plantago major, and in other cases, with confirmatory pharmacological studies, such as Larrea divaricata (Davicino et al., 2011)

An aspect to highlight in the list of species are those that are used in the region but that could not be documented since they do not grow in the study area, being the main form of acquisition in herbal stores in nearby cities. These are species whose common names coincide with those outlined in other studies carried out in the Puna (Palma, 1973; Pérez de Nucci, 1988) and in the Yungas (Hilgert, 2001; Hilgert and Gil, 2007), such is the case of vira-vira (cfr. Achyrocline spp.), yareta (cfr. Azorella sp.), muña-muña (cfr. Clinopodium gilliesii (Benth.) Kuntze), chachacoma (cfr. Senecio nutans Sch. Bip.) and salvia de la Puna (cfr. Salvia cuspidata Ruiz and Pav. subsp. gilliesii (Benth.) J.R.I. Wood.). Despite the low relative frequency of citations, these similarities highlight the contact of the herbalism and the criollo population of Ancasti with that of the native peoples of the Puna and the Yungas. Likewise, there are also other species in common use in the Yungas (Hilgert, 2001) and in Ancasti, mainly exotic species, that are part of many other pharmacopoeias in central Argentina and other Latin American regions. For instance, we can mention species such as Citrus spp., Cydonia oblonga Miller, Ruta chalepensis, Eucalyptus sp., Foeniculum vulgare Mill., Ilex paraguariensis, Matricaria chamomilla L., Melissa officinalis L., Aloysia citriodora Palau, Punica granatum L., Prunus persica (L.) Batsch, Rosmarinus officinalis, Tanacetum vulgare L., among other. On the contrary, most of the list make up a pharmacopoeia with a large number of exclusive recipes for the region, which gives it originality and accounts for the autonomy of the inhabitants to manage their own medicinal resources.

\section{Relative Importance}

Table 2 shows the species with values above the mean plus a standard deviation $(23+19=42)$ of their RI. The RI of plant species is a useful parameter to measure their versatility. The RI index, which considers the total pharmacological properties attributed (PH) and body systems or health areas involved (BS) in the use of medicines, the plant arrangement listed in Table 2, again highlights some species that stand out for their number of uses: Sphaeralcea bonaeriensis, Rosmarinus officinalis, Vachellia caven, Cestrum parqui, Aloe spp., Ruta chalepensis, Larrea divaricata, Ilex paraguariensis and Plantago major. However, this type of versatile analysis highlights other species rarely referred to in the previous studies, as in the case of Lithraea molleoides and Ficus carica.

Plants with the highest RI indicate that they are more versatile and used primarily by the inhabitants in the area, that they

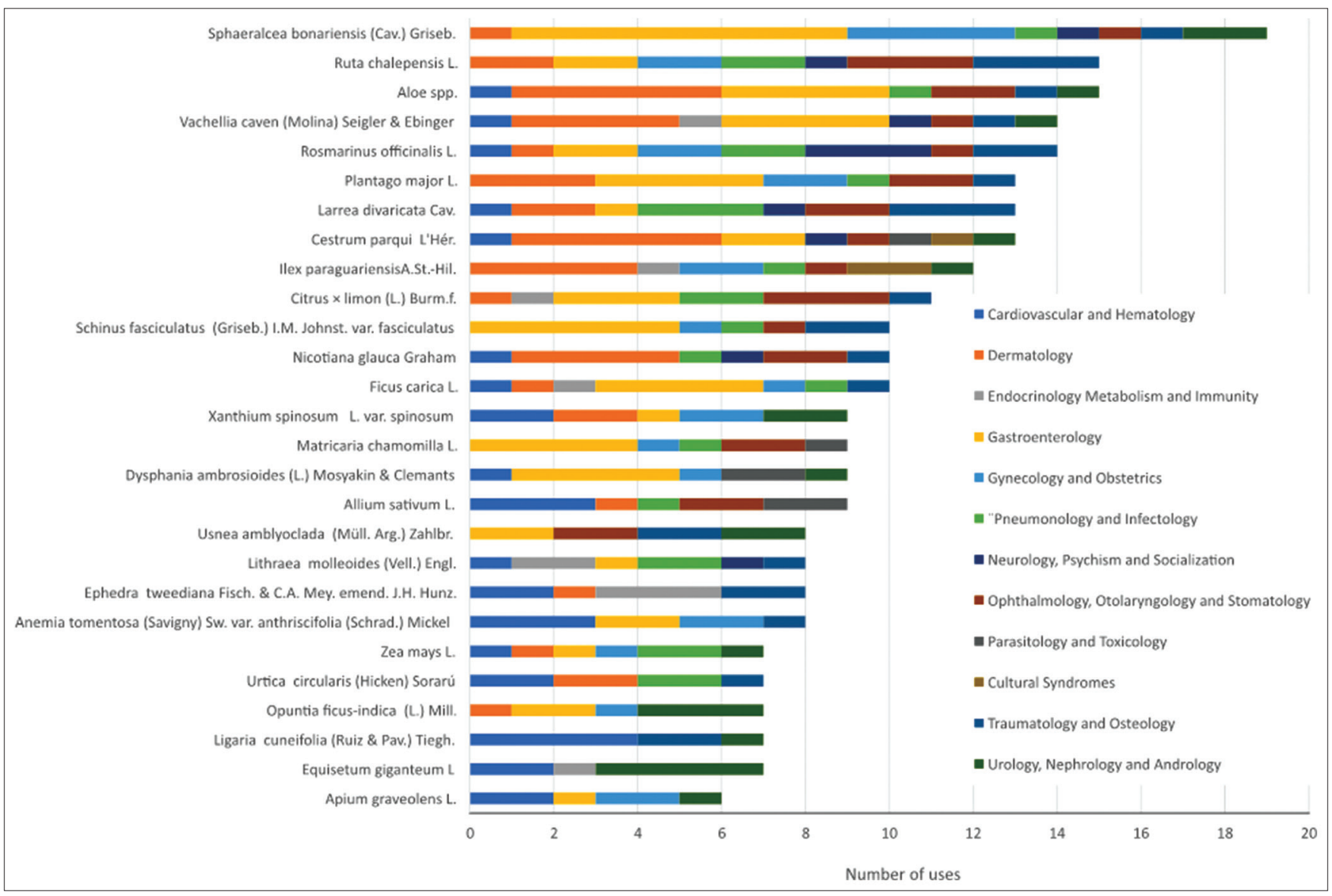

Figure 3: Species with higher amounts of medicinal uses and applications 
Table 2: Species with RI values above the mean plus a standard deviation $(23+19=42)$.

\begin{tabular}{|c|c|c|c|c|c|}
\hline & $\begin{array}{l}\text { Count } \\
\text { BS }\end{array}$ & $\begin{array}{l}\text { Rel } \\
\text { BS }\end{array}$ & $\begin{array}{l}\text { Count } \\
\mathrm{PH}\end{array}$ & Rel PH & RI \\
\hline $\begin{array}{l}\text { Sphaeralcea bonariensis (Cav.) } \\
\text { Griseb. }\end{array}$ & 8 & 1,00 & 19 & 1,00 & 100,00 \\
\hline Rosmarinus officinalis L. & 8 & 1,00 & 14 & 0,74 & 86,84 \\
\hline $\begin{array}{l}\text { Vachellia caven (Molina) Seigler } \\
\text { \& Ebinger }\end{array}$ & 8 & 1,00 & 14 & 0,74 & 86,84 \\
\hline Cestrum parqui L'Hér. & 8 & 1,00 & 13 & 0,68 & 84,21 \\
\hline Aloe spp. & 7 & 0,88 & 15 & 0,79 & 83,22 \\
\hline Ruta chalepensis L. & 7 & 0,88 & 15 & 0,79 & 83,22 \\
\hline Larrea divaricata Cav. & 7 & 0,88 & 13 & 0,68 & 77,96 \\
\hline Ilex paraguariensisA.St.-Hil. & 7 & 0,88 & 12 & 0,63 & 75,33 \\
\hline Plantago major $\mathrm{L}$. & 6 & 0,75 & 13 & 0,68 & 71,71 \\
\hline Ficus carica L. & 7 & 0,88 & 10 & 0,53 & 70,07 \\
\hline Citrus x limon (L.) Burm.f. & 6 & 0,75 & 11 & 0,58 & 66,45 \\
\hline Nicotiana glauca Graham & 6 & 0,75 & 10 & 0,53 & 63,82 \\
\hline Lithraea molleoides (Vell.) Engl. & 6 & 0,75 & 8 & 0,42 & 58,55 \\
\hline $\begin{array}{l}\text { Schinus fasciculatus (Griseb.) I.M. } \\
\text { Johnst. var. fasciculatus }\end{array}$ & 5 & 0,63 & 10 & 0,53 & 57,57 \\
\hline Zea mays L. & 6 & 0,75 & 7 & 0,37 & 55,92 \\
\hline Allium sativum $\mathrm{L}$. & 5 & 0,63 & 9 & 0,47 & 54,93 \\
\hline $\begin{array}{l}\text { Dysphania ambrosioides (L.) } \\
\text { Mosyakin \& Clemants }\end{array}$ & 5 & 0,63 & 9 & 0,47 & 54,93 \\
\hline Matricaria chamomilla L. & 5 & 0,63 & 9 & 0,47 & 54,93 \\
\hline $\begin{array}{l}\text { Xanthium spinosum L. var. } \\
\text { spinosum }\end{array}$ & 5 & 0,63 & 9 & 0,47 & 54,93 \\
\hline Artemisia abrotanum L. & 5 & 0,63 & 6 & 0,32 & 47,04 \\
\hline Origanum vulgare $\mathrm{L}$. & 5 & 0,63 & 6 & 0,32 & 47,04 \\
\hline $\begin{array}{l}\text { Schkuhria pinnata (Lam.) Kuntze } \\
\text { ex Thell. }\end{array}$ & 5 & 0,63 & 6 & 0,32 & 47,04 \\
\hline Vitis vinifera $\mathrm{L}$. & 5 & 0,63 & 6 & 0,32 & 47,04 \\
\hline $\begin{array}{l}\text { Anemia tomentosa (Savigny) Sw. } \\
\text { var. anthriscifolia (Schrad.) Mickel }\end{array}$ & 4 & 0,50 & 8 & 0,42 & 46,05 \\
\hline $\begin{array}{l}\text { Ephedra tweediana Fisch. \& C.A. } \\
\text { Mey. emend. J.H. Hunz. }\end{array}$ & 4 & 0,50 & 8 & 0,42 & 46,05 \\
\hline $\begin{array}{l}\text { Usnea amblyoclada (Müll. Arg.) } \\
\text { Zahlbr. }\end{array}$ & 4 & 0,50 & 8 & 0,42 & 46,05 \\
\hline Opuntia ficus-indica (L.) Mill. & 4 & 0,50 & 7 & 0,37 & 43,42 \\
\hline Urtica circularis (Hicken) Sorarú & 4 & 0,50 & 7 & 0,37 & 43,42 \\
\hline
\end{tabular}

have more powerful pharmacological properties, and that their importance increases when they are used to cure more diseases (Albuquerque et al., 2006).

Life-forms, parts used and way of consumption of the species

Regarding the most relevant life-forms, herbs were leading with a $45.1 \%$ contribution, followed by shrubs (25.3\%), trees (23.6\%), climbers $(5.1 \%)$, and fungi $(0.8 \%)$.

Figure 4 shows that the most used parts are leaves (29\%), followed by flowering aerial parts (19\%), fruits (18\%), stems $(11 \%)$, whole plant $(6 \%)$, while the contribution of the roots, flowers-inflorescences, and bark is less than 5\%; finally, other parts contribute the remaining $12 \%$. In this sense, leaves contain a high concentration of health-beneficial phytochemicals and essential oils, which contribute significantly to phytotherapy or the treatment of various health disorders (Mahmood et al., 2013; Bano et al., 2014). Likewise, roots are rich in bioactive constituents compared to other parts. However, previous studies reveal that most researchers prefer to use leaves to that of roots and cortex because eradicating the latter could lead to more severe problems in the conservation of species. This percentage distribution is similar to that of other studies in which the leaves lead the percentage of parts used in the total of medicinal uses (Martínez 2007, 2008, 2010; Leto et al., 2013).

With respect to the way of consumption, decoction and infusion were the most widely used modes of preparation with a percentage contribution of $68 \%$, followed by direct application (4\%), incineration (4\%), ground (3\%), and maceration in alcohol (2\%), respectively; finally, other fourty six different way of consumption contribute the remaining $19 \%$. The frequent use of decoction had also been reported previously (Arias Toledo, 2009; Martínez, 2010; Gürdal and Kültür, 2013; Tugume et al., 2016; Luján and Martínez, 2017; Luján et al., 2017; Umair et al., 2019; Farooq

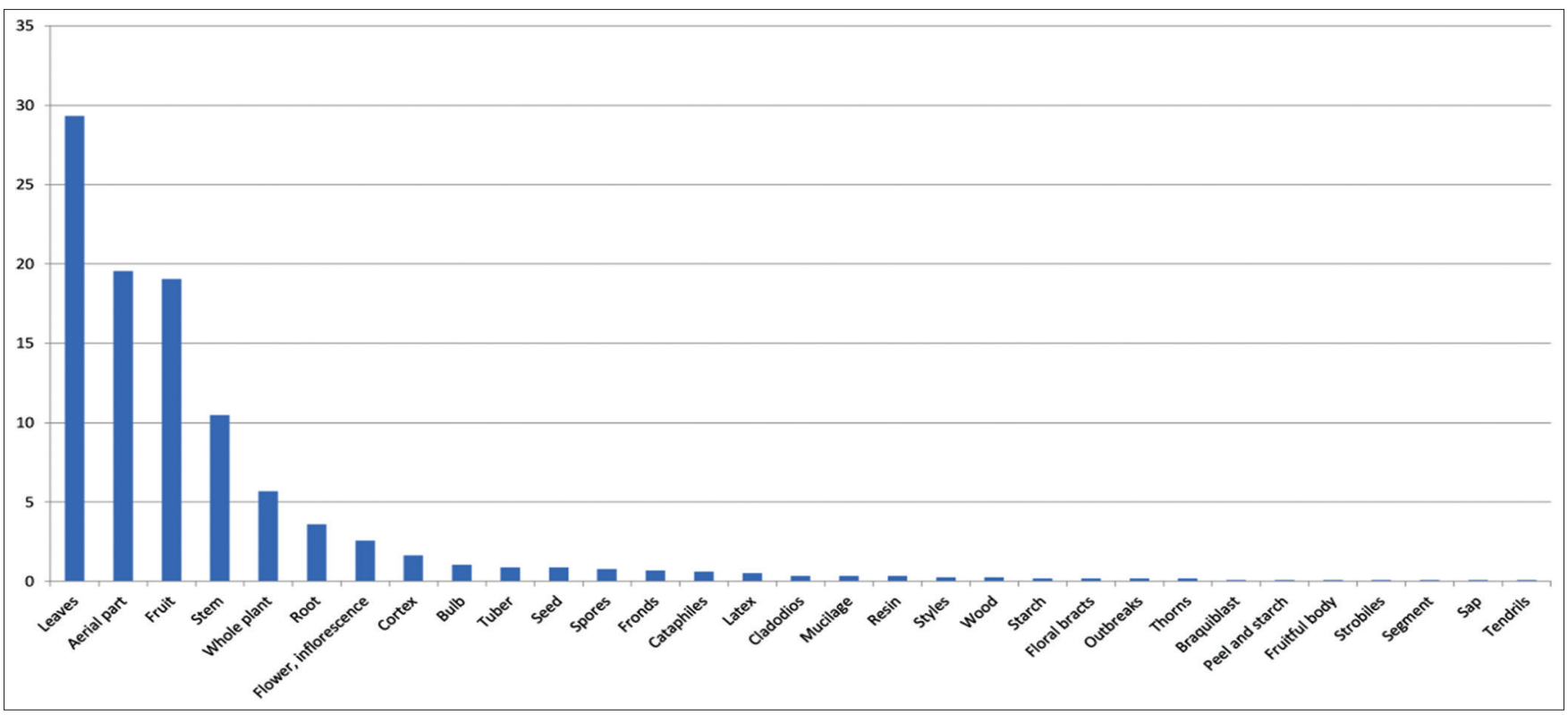

Figure 4: Percentage of each plant-part in the total of medicinal uses 
et al., 2019). This confirms that the preparation of decoctions is a simple and straightforward form used in herbal preparations with greater health benefits. In decoctions, the effectiveness of medicinal herbs increases due to the thermal extraction of a great number of secondary metabolites beneficial to health and other bioactive components. In the oral administration mode, the plant materials were mainly ingested as a decoction or in infusion form. Oral administration of herbal preparations is usually effective for the treatment of internal ailments, while external ailments (for example, skin, joint, or hemorrhoid conditions) were treated by topical applications, such as poultices, juices and friction. These observations were in agreement with previous reports (Uzun and Kaya, 2016). One aspect to be highlighted is that brief association was found between the mode of preparation and administration and the principle of opposition warm-fresh that, as previously mentioned, is restricted to very few cases.

\section{2) Different body systems}

Figure 5 highlights that the greatest numbers of uses and species are intended for applications in the gastroenterology and cardiovascular medicine and hematology area, followed by skin ailments, which is consistent with the most common applications in other regions of central Argentina where species for use in digestive disorders predominate (Arias Toledo, 2009; Martínez, 2010; Luján and Martínez, 2017; Luján et al., 2017).

\section{Informant Consensus Factor of species and uses per health area}

Based on the informant consensus about the medicinal applications in various health areas, Table 3 shows that the greatest flow of shared information and the most defined criteria in the choice of medicinal species among informants are observed in the treatment of gastrointestinal $(\mathrm{ICF}=0.44$ ) and skin conditions $(\mathrm{ICF}=0.39)$. The low consensus values for the species used in the treatment of cultural syndromes $(\mathrm{ICF}=0.20)$ and neurology, psychism and socialization ailments $(\mathrm{ICF}=0.14)$ associated with few use reports are indicators of the exclusivity of certain information with a cultural nature, which means that this knowledge is poorly shared or exchanged between informants.

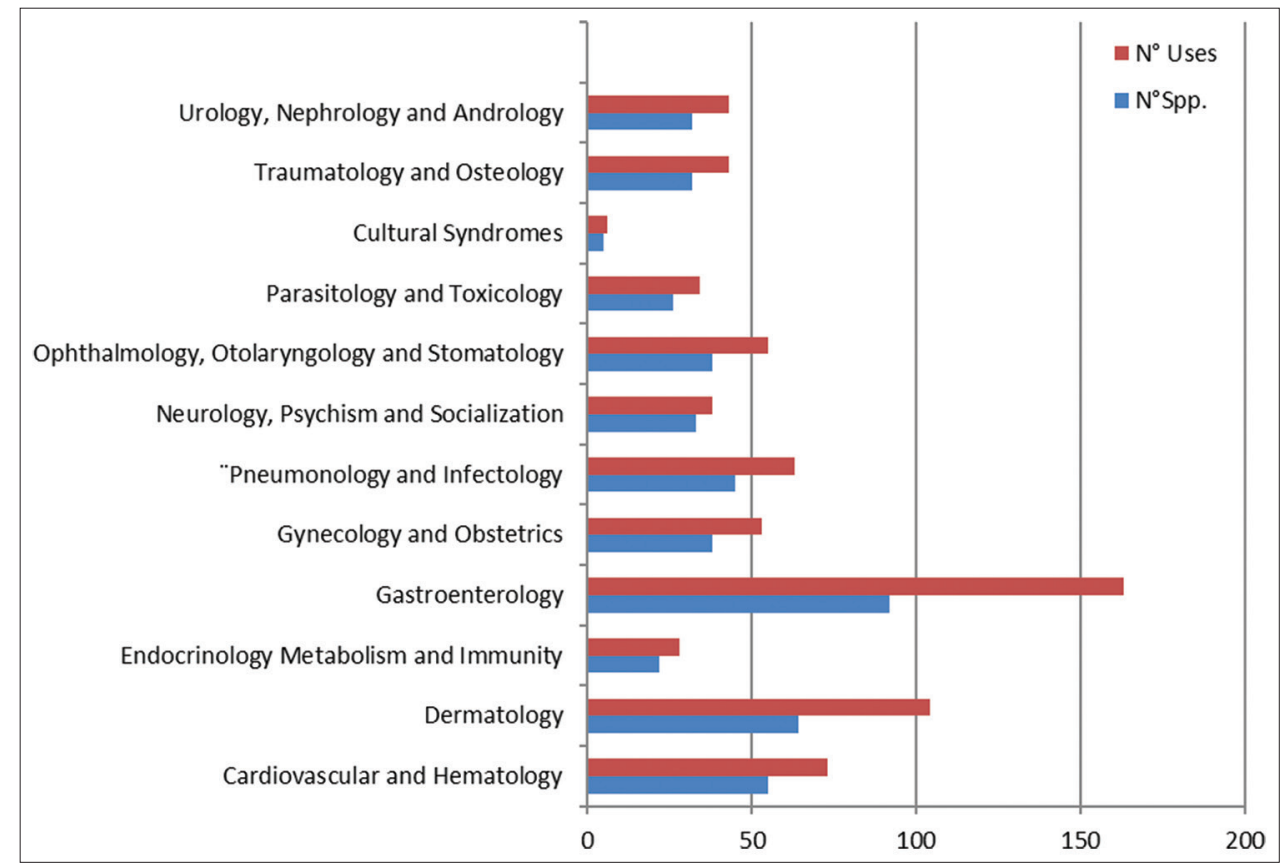

Figure 5: Number of uses and species per category of health area.

Table 3: Arrangement of health areas according to their descending ICF values.

\begin{tabular}{|c|c|c|c|c|c|c|}
\hline Health area & $\mathrm{N}^{0}$ SPECIES & $\%$ SPECIES & $\mathrm{N}^{0}$ USES & $\%$ USES & Ration $\mathrm{N}^{0}$ Uses / $\mathrm{N}^{0} \mathrm{Sp}$ & ICF \\
\hline Gastroenterology & 92 & 19,09 & 163 & 23,19 & 1,77 & $\overline{0,44}$ \\
\hline Dermatology & 64 & 13,28 & 104 & 14,79 & 1,63 & 0,39 \\
\hline Ophthalmology, otolaryngology and stomatology & 38 & 7,88 & 55 & 7,82 & 1,45 & 0,31 \\
\hline Cardiovascular and hematology & 55 & 11,41 & 73 & 10,38 & 1,33 & 0,25 \\
\hline Pneumonology and infectology & 45 & 9,34 & 63 & 8,96 & 1,40 & 0,29 \\
\hline Ginecology and obstetrics & 38 & 7,88 & 53 & 7,54 & 1,39 & 0,29 \\
\hline Traumatology and osteology & 32 & 6,64 & 43 & 6,12 & 1,34 & 0,26 \\
\hline Urology, nephrology and andrology & 32 & 6,64 & 43 & 6,12 & 1,34 & 0,26 \\
\hline Parasitology and toxicology & 26 & 5,39 & 34 & 4,84 & 1,31 & 0,24 \\
\hline Endocrinology, metabolism and immunity & 22 & 4,56 & 28 & 3,98 & 1,27 & 0,22 \\
\hline Cultural syndromes & 5 & 1,04 & 6 & 0,85 & 1,20 & 0,20 \\
\hline Neurology, psychism and socialization & 33 & 6,85 & 38 & 5,41 & 1,15 & 0,14 \\
\hline
\end{tabular}




\section{CONCLUSIONS}

The medicinal flora in Ancasti, Catamarca is highly diverse and was scarcely explored so far; the present article is the first systematic study in this area and describes the use of 214 medicinal plant species as part of the natural pharmacopoeia of its residents. The present study and the indices applied highlight the relevance of medicinal species such as Sphaeralcea bonariensis, Vachellia caven, Ruta chalepensis, Rosmarinus officinalis, Cestrum parqui, Aloe spp., Plantago major, Larrea divaricata, Ilex paraguariensis among other. It is necessary to avoid the extinction of this ethnobotanical heritage through the participation of interested authorities, conservation administrators and the academy. The figure of the healer or traditional practitioner is not central to the treatment and management of specialized diseases and ailments with medicinal plants, rather these are more common in their use in the framework of domestic and homemade medicine or in self-treatment where the application of medicinal plants listed in this article takes place.

An aspect that needs further research is the ethnomedicinal knowledge that underlies the vast list of plants and uses documented here. In this sense, the study of the context of the utilization of these species is promising, for example, the etiology of the ailments, the forms of diagnosis and the therapeutic itineraries. This is so because the local people are bearers of a rich wisdom that could contribute to deepen upcoming studies. Likewise, the variety of the pharmacopoeia of Ancasti and its points of intercultural contact with other regions (Norwheast and Central Argentina) make it possible to differentiate exotic (mainly present in gardens) and native wild species collected in situ, from those acquired in markets; its more in-depth study will allow making inferences regarding the impact of its extraction for conservation, especially in the case of those species with higher medicinal importance.

\section{ACKNOWLEDGMENTS}

We are grateful to Sierra de Ancasti's inhabitants for their time and generosity, without their collaboration, this work would not have been possible. To the Secretary of the Environment of Catamarca for the permits granted. To Mgtr. Carolina Mosconi for her valuable contribution with language revision. To IDACOR and the Museum of Anthropology. To IMBIV and its staff for the care of the collection of deposited plants. This study was funded by Conicet and Foncyt Pict 1633 and 2469 projects.

\section{REFERENCES}

Albuquerque, U. P., Lucena, R. F., Monteiro, J. M., Florentino, A. T., and Almedia, C. F. C. (2006). Evaluationg two quantitative ethnobotanical techniques. Ethnobotany Research and Applications, 4, 51-60. https:// doi.org/10.17348/era.4.0.51-60

Albuquerque, U., Lucena, R. F. P., and Alencar, N. L. (2010). Métodos e técnicas para a coleta de dados etnobiologicos, In U. P. Albuquerque, R. F. P Lucena and L. V. F. Cunha (Eds.), Métodos e técnicas na pesquisa etnobiologica e etnoecologica (pp. 39-63), Recife, Brasil: Editora NUPEEA.

Alexiades, M. N. (1996). Protocol for conducting ethnobotanical research in the Tropics, In M. N. Alexiades (Eds.), Selected guidelines for ethnobotanical research: A field manual (pp. 5-18), Bronx, New York: New York Botanical Garden.

Alonso, J. R., and Desmarchelier, C. (2005). Plantas medicinales autóctonas de la Argentina. Buenos Aires: Ed. L.O.L.A.

Anderson, E. N., Persall, D. M., Hunn, E.S. and Turner, N. J. (2011). Ethnobiology, Hoboken-New Jersey, United States: John Wiley and Sons, Inc.

Arenas, P. (1995). Ethnobotanical survey applied to indigenous people of the Gran Chaco (in Spanish). Towards a new ethnic chart of the Gran Chaco, 6, 161-178

Arias Toledo, B. (2006). Aspectos cuantitativos, cualitativos y simbólicos de la medicina tradicional de los pobladores criollos de Cerro Colorado (Córdoba, Argentina). PINACO, Antropología Cognitiva, 4, 105-115.

Arias Toledo, B. (2009). Diversidad de usos, prácticas de recolección y diferencias según género y edad en el uso de plantas medicinales en Córdoba, Argentina. Boletín Latinoamericano y del Caribe de Plantas Medicinales y Aromáticas, 8(5), 389-401.

Arias Toledo, B., Galetto, L., and Colantonio, S. (2007). Uso de plantas medicinales y alimenticias según características socioculturales en Villa Los Aromos (Córdoba, Argentina). Kurtziana, 33(1), 79-88.

Arias Toledo, B., Galetto, L., and Colantonio, S. (2009). Ethnobotanical knowledge in rural communities of Cordoba (Argentina): The importance of cultural and biogeographical factors. Journal of Ethnobiology and Ethnomedicine, 5(1), 40. https://doi. org/10.1186/1746-4269-5-40

Arias Toledo, B., Trillo, C., and Grilli, M. (2010). Uso de plantas medicinales en relación al estado de conservación del bosque en Córdoba, Argentina. Ecología Austral, 20(3), 235-246.

Bano, A., Ahmad, M., Hadda, T. B., Saboor, A., Sulltana, S., Zafar, M., Khan, M. P. Z., Arshad, M., and Ashraf, M. A. (2014). Quantitative ethnomedicinal study of plants used in the skardu valley at high altitude of Karakoram - Himalayan range, Pakistan. Journal of Ethnobiology and Ethnomedicine, 10(1), 43. https://doi. org/10.1186/1746-4269-10-43.

Barboza, G. E., Cantero, J. J., Núñez, C. O. and Ariza Espinar, L. (2006). Flora medicinal de la Provincia de Córdoba (Argentina): Pteridófitas y Antófitas silvestres o naturalizadas. Córdoba, Argentina: Ed. Museo Botánico.

Barboza, G. E., Cantero, J. J., Núñez, C. O., Pacciaroni, A., and Ariza Espinar, L. (2009). Medicinal plants: A general review and a phytochemical and ethnopharmacological screening of the native Argentine Flora. Kurtziana, 34 (1-2), 7-365.

Baydoun, S., Chalak, L., Dalleh, H., and Arnold, N. (2015). Ethnopharmacological survey of medicinal plants used in traditional medicine by the communities of mount Hermon, Lebanon. Journal of Ethnopharmacology, 173, 139-56. https://doi.org/10.1016/j. jep.2015.06.052.

Bennet, B. C., and Prance, G. T. (2000). Introduced plants in the Indigenous pharmacopoeia of northern South America. Economic Botany, 54, 90-102. https://doi.org/10.1007/BF02866603.

Bolson, M., Hefler, S. R., Chaves, E. I. D. O., Junior, A. G., and Junior, E. L. C. (2014). Ethno-medicinal study of plants used for treatment of human ailments, with residents of the surrounding región of forest fragments of Paraná, Brazil. Journal of Ethnopharmacology, 161, 1-10. https:// doi.org/10.1016/j.jep.2014.11.045

Cantero, J. J., Barboza, G. E., Chiarini, F., and Ariza Espinar, L. (2015). Plantas del Famatina, Córdoba: Academia Nacional de Ciencias, Universidad Nacional de Córdoba.

Davicino, R., Martino, R., and Anesini, C. (2011). Larrea divaricata Cav.: Scientific evidence showing its beneficial effects and its wide potencial application, Boletín Latinoamericano y de/ Caribe de Plantas Medicinales y Aromáticas, 10(2), 92-103.

Farooq, A., Amjad, M. S., Ahmad, K., Altaf, M., Umair, M., and Mehmood Abbasi, A. (2019). Ethnomedicinal knowledge of the rural communities of Dhirkot, Azad Jammu and Kashmir, Pakistan. Journal of Ethnobiology and Ethnomedicine, 15, 45. https://doi.org/10.1186/ s13002-019-0323-2

Foster, G. M. (1994). Hipocrates' Latin American Legacy. Humoral medicine in the new world, New York: Gordon and Breach Science Pubishers.

Goleniowski, M., Bongiovanni, G. A., Palacio, L., Nuñez, C. O., and Cantero, J. J. (2006). Medicinal plants from the "Sierra de Comechingones", Argentina. Journal of Ethnopharmacology, 107(3), 324-341. https://doi.org/10.1016/j.jep.2006.07.026 
Gürdal, B., and Kültür, Ş. (2013). An ethnobotanical study of medicinal plants in Marmaris (Muğla, Turkey). Journal of Ethnopharmacology, 146(1), 113-26. https://doi.org/10.1016/j.jep.2012.12.012

Heinrich, M., Ankli, A., Frei, B., Weimann, C., and Sticher, O. (1998). Medicinal plants in Mexico: healers' consensus and cultural importance. Social Science and Medicine, 47, 1859-1871. https:// doi.org/10.1016/S0277-9536(98)00181-6

Hilgert, N. I. (2001). Plants used in home medicine in the Zenta River basin, Northwest Argentina. Journal of Ethnopharmacology, 76(1), 11-34. https://doi.org/10.1016/S0378-8741(01)00190-8

Hilgert, N. I., and Gil, G. (2007). Reproductive medicine in northwest Argentina: traditional and institutional systems. Journal of Ethnobiology and Ethnomedicine, 3, 19. https://doi.org/10.1186/17464269-3-19

Idoyaga Molina, A. (2000). La medicina humoral, las nociones de cálido y frío y las prácticas terapéuticas tradicionales en la Argentina., In A. Colatarci (Eds.), Folklore Latinoamericano (Vol. 3, pp.259-298), Buenos Aires: Prensa del INSPF-IUNA.

INDEC. (2010). Instituto Nacional de Estadística y Censos. República de Argentina. Retrieved from http://www.indec.gov.ar

International Society of Ethnobiology. (2006). International Society of Ethnobiology Code of Ethics (with 2008 additions). Retrieved from http://ethnobiology.net/code-of-ethics

Jiménez-Escobar, N. D. (2019). Ciclo de las plantas forrajeras: dinámicas y prácticas de una comunidad ganadera del Chaco Seco, Argentina. Ethnobotany Research and Applications, 18(39), 1-22.

Jiménez-Escobar, N. D., and Martínez, G. J. (2019). Firewood knowledge, use and selection by rural populations in the Dry Chaco of Sierra de Ancasti, Catamarca, Argentina. Ethnobiology and Conservation, 8(3). https://doi.org/10.15451/ec2019-01-8.03-1-19

Kadir, M. F., BinSayeed, M. S., IslamSetu, N., Mostafa, A., and Mia, M. (2014). Ethnopharmacological survey of medicinal plants used by traditional health practitioners in Thanchi, Bandarban Hill Tracts, Bangladesh. Journal of Ethnopharmacology, 155(1), 495-508. https:// doi.org/10.1016/j.jep.2014.05.043

Karlin, U. O. (2006). Huellas de identidad, Uso y conservación de las plantas en Tudcum, Malimán y Angualasto, San Juan: $1^{\circ}$ edic. del autor.

Karlin, U., Martinelli, M., Gaviorno, M., Díaz, G., and Ordóñez, C. (2005). Saberes que Sanan. Plantas con uso medicinal en Balde del Rosario, San Juan, Argentina: Ed. Univ. Nac. San Juan. Facultad de Ciencias Exactas, Físicas y Naturales.

Leto, C., Tuttolomondo, T., La Bella, S., and Licata, M. (2013). Medicinal use of wild shrub and herbaceous plant species. Ethnobotanical study in the Madonie Regional Park (Central Sicily, Italy). Journal of Ethnopharmacology, 146(1), 90-112. https://doi.org/10.1016/j. jep.2012.11.042

Luján, M. C., Martínez, G. J., and Bárcena, B. (2011). Entre hierbas y yuyos serranos. Actores, saberes y prácticas de la flora medicinal en las sierras de Córdoba. Una experiencia en las inmediaciones del Dique Los Molinos. Córdoba, Argentina: Editorial Universidad Nacional de Córdoba.

Luján, M. C., Barboza, G. E., and Martínez, G. (2017). Confluencia de experiencias etnomédicas y uso de plantas medicinales en practicantes nativos del Valle de Traslasierra (Departamento San Javier), Córdoba, Argentina. Boletín de la Sociedad Argentina de Botánica, 52(4), 797-815. https://doi.org/10.31055/1851.2372.v52. n4. 18873

Luján, M. C., and Martínez, G. (2017). Dinámica del conocimiento etnobotánico en poblaciones urbanas y rurales de Córdoba (Argentina). Boletín Latinoamericano y del Caribe de Plantas Medicinales y Aromáticas, 16(3), 278-302.

Lulekal, E., Kelbessa, E., Bekele, T., and Yineger, H. (2008). An ethnobotanical study of medicinal plants in Mana Angetu District, southeastern Ethiopia. Journal of Ethnobiology and Ethnomedicine, 4, 10. https://doi.org/10.1186/1746-4269-4-10

Mahmood, A., Mahmood, A., Malik, R. N., and Shinwari, Z. K. (2013). Indigenous knowledge of medicinal plants from Gujranwala district, Pakistan. Journal of Ethnopharmacology, 148(2), 714-723. https://doi. org/10.1016/j.jep.2013.05.035

Maldonado, V. P. (2011). Plan Estratégico Territorial de la Provincia de Catamarca: Informe de Avance I/: año 2011, 1a ed. Catamarca: Gobierno de Catamarca.

Martin, G. (2001). Etnobotánica. Manual de Conservación. Serie "Pueblos y Plantas". WWF-UK. Kew, Reino Unido: UNESCO y Royal Botanic
Gardens. Montevideo, Uruguay: Ed. Nordan Comunidad,

Martínez, G. J. (2005). Recolección y comercialización de plantas medicinales en el Departamento Santa María, Provincia de Córdoba. Acta Farmacéutica Bonaerense, 24(4), 84-575.

Martínez, G. J. (2007). Medicinal plants used by the 'Criollos' of Calamuchita to treat blood, cardiovascular and neuroendocrinous diseases. Journal of Herbs Spices and Medicinal Plants, 13, 22-54.

Martínez, G. J. (2008). Farmacopea natural y tratamiento de afecciones de la piel en la medicina tradicional de los campesinos de las sierras de Córdoba (República Argentina). Dominguezia, 24(1), 27-46.

Martínez, G. J. (2010). Las plantas en la medicina tradicional de las sierras de Córdoba. Un recorrido por la cultura campesina de Paravachasca y Calamuchita. Córdoba, Argentina: Ed. Del Copista.

Martínez, G. J. and Planchuelo, A. M. (2003). La medicina tradicional de los criollos campesinos de Paravachasca y Calamuchita, Córdoba (Argentina). Scripta Ethnologica, 25, 83-116.

Menseguez, P., Galetto, L., and Anton, A. (2007). El uso de plantas medicinales en la población campesina de El Puesto (Córdoba, Argentina). Kurtziana, 33(1), 89-102.

Moerman, D. E., Pemberton, R. W., Kiefe, D., and Berlin, B. (1999). A comparative analysis of five medicinal floras. Journal of Ethnobiology, 19(1), 49 - 70.

Morláns, M. C. (1995). Regiones Naturales de Catamarca, Provincias Geológicas y Provincias Fitogeográficas. Revista de Ciencia y Técnica, 2(2), 1-42.

Ochoa, V., and Fernández, R. (2014). Análisis participativo de la situación de salud del Departamento Ancasti, Provincia de Catamarca. Revista de Salud Pública, 15(2), 36-47.

Palmeri, C. N., Carma, I. M., and Quiroga, A. (2008). Las Ecorregiones de Catamarca. Atlas de Catamarca. Universidad Nacional de Catamarca, Facultad de Ciencias Agrarias. Retreived from http://www.atlas. catamarca.gov.ar

Phillips, O., and Gentry, A. H. (1993). The Useful Plants of Tambopata, Peru: I. Statistical Hypotheses Tests with A New Quantitative Technique. Economic Botany, 47, 15-32. https://doi.org/10.1007/ BF02862203

Palma, N. H. (1973). Estudio antropológico de la medicina popular de la Puna Argentina. Buenos Aires, Argentina: Ediciones Cabargon.

Pérez de Nucci, A. (1988). La medicina tradicional del Noroeste Argentino. Historia y presente. Buenos Aires, Argentina: Ediciones del Sol Colihue.

Prance, G. T., Balee, W., Boom, B. M., and Carneiro, R. L. (1987). Quantitative Ethnobotany and the Case for Conservation in Ammonia. Conservation Biology, 1(4), 296-310. https://doi. org/10.1111/j.1523-1739.1987.tb00050.x

Qaseem, M., Qureshi, R., Amjad, M. S., Ahmed, W., Masood, A., and Shaheen, H. (2019). Ethnobotanical evaluation of indigenous flora from the communities of Rajh Mehal and Goi Union councils of district Kotli, Azad Jammu Kashmir Pakistan. Applied Ecology and Environmental Research, 17(2), 2799 - 282 https://doi.org/10.15666/ aeer/1702 27992829

Rifkin, S. B. (2007). Rapid rural appraisal: Its use and value for health planners and managers. Public Administration, 74(3), 509 - 526. https://doi.org/10.1111/j.1467-9299.1996.tb00882.x

Rossato, S., Leitão-Filho, H. F., and Begossi, A. (1999). Ethnobotany of Caiçaras of the Atlantic Forest Coast (Brazil). Economic Botany, 53, 387-395. https://doi.org/10.1007/BF02866716

Tabuti, J., Lye, K., and Dhillion, S. (2003). Traditional herbal drugs of Bulamogi, Uganda: plants, use and administration. Journal of Ethnopharmacology, 88(1), 19-44. https://doi.org/10.1016/S03788741(03)00161-2

Trillo, C., Arias Toledo, B., Galetto, L., and Colantonio, S. (2010). Persistence of the use of medicinal plants in rural communities of the Western Arid Chaco (Córdoba, Argentina). The Open Complementary Medicine Journal, 2, 80-89.

Trotter, R. and Logan, M. (1986). Informant consensus: a new approach for identifying potentially effective medicinal plants. In N. L. Etkin (Eds.), Indigenous medicine and diet: biobehavioral approaches (pp.91-112), New York, USA: Redgrave Bedford Hills Ed.

Tugume, P., Kakudidi, E. K., Buyinza, M., Namaalwa, J., Kamatenesi, M., Mucunguzi, P., and Kalema, J. (2016). Ethnobotanical survey of medicinal plant species used by communities around Mabira central Forest reserve, Uganda. Journal of Ethnobiology and Ethnomedicine, 12, 5. https://doi.org/10.1186/s13002-015-0077-4 
Umair, M., Altaf, M., Bussmann, R. W., and Abbasi, A. M. (2019). Ethnomedicinal uses of the local flora in Chenab riverine area, Punjab province Pakistan. Journal of Ethnobiology and Ethnomedicine, 15, 7. https://doi.org/10.1186/s13002-019-0285-4

Uzun, M., and Kaya, A. (2016). Ethnobotanical research of medicinal plants in Mihalgazi (Eskişehir, Turkey). Pharmaceutical Biology, 54(12), 29222932. https://doi.org/10.1080/13880209.2016.1194863

Villafuerte, C. (1961). Voces y costumbres de Catamarca. 2 Tomos. Argentina: Academia Argentina de Letras.
W.H.O. (1978a). World Health Organization. Promoción y desarrollo de la medicina tradicional. Ginebra.

W.H.O. (1978b). World Health Organization. Drug Policies and Management: Medicinal Plants. WHO Document WHA 31.33. Geneva, Italy.

Zuloaga, F. O., Morrone, O., and Belgrano, M. J. (2008). Catálogo de Plantas Vasculares del Cono Sur. Monogr. Missouri Bot. Garden (USA). Retreived from: http://www2.darwin.edu.ar/proyectos/ floraargentina/Generos 